Revue d'histoire de l'Amérique française

DE REVUE D.HISTOIRE DE L'AMÉRIQUE FRANÇAISE

\title{
Bibliographie d'histoire de l'Amérique française (publications récentes)
}

\section{Centre de bibliographie historique de l'Amérique française}

Volume 38, numéro 1, été 1984

URI : https://id.erudit.org/iderudit/304252ar

DOI : https://doi.org/10.7202/304252ar

Aller au sommaire du numéro

Éditeur(s)

Institut d'histoire de l'Amérique française

ISSN

0035-2357 (imprimé)

1492-1383 (numérique)

Découvrir la revue

Citer ce document

Centre de bibliographie historique de l'Amérique française (1984).

Bibliographie d'histoire de l'Amérique française (publications récentes). Revue

d'histoire de l'Amérique française, 38(1), 114-146.

https://doi.org/10.7202/304252ar d'utilisation que vous pouvez consulter en ligne. 


\section{BIBLIOGRAPHIE D'HISTOIRE DE L'AMÉRIQUE FRANÇAISE \\ (PUBLICATIONS RÉCENTES)}

préparée depuis 1967 par le

Centre de bibliographie historique de l'Amérique française

sous la direction de Paul AUBIN (Institut québécois de recherche sur la culture) et Paul-André LINTEAU (Université du Québec à Montréal)

Cette bibliographie est réalisée à partir du dépouillement systématique de plus de 400 périodiques.

Tous ces titres, de même que ceux-là que, faute d'espace, nous ne mentionnons pas dans la chronique de la Revue, sont ensuite versés dans la banque informatisée HISCABEQ; le recours à cette banque offre au chercheur la possibilité d'une mise à jour cumulative des données bibliographiques dans le ou les champs de recherche qui l'intéressent.

\section{I - LES CIVILISATIONS AMÉRINDIENNES ET LES PREMIÈRES DÉCOUVERTES}

1. ANDERSON, Karen. Barriers and incentives to the expansion of Huron horticulture circa 1616-1648. [Toronto], Département de Sociologie, Université de Toronto, 1982. 27 p.

2. ANDERSON, Karen. Commodity exchange and subordination: a comparison of Montagnais-Naskapi and Huron women circa 1600-1650. [Toronto], Département de Sociologie, Université de Toronto, 1983. 31 p.

3. ARCHER, Christon I. «The transient presence: a re-appraisal of Spanish attitudes toward the northwest coast in the eighteenth century", W. Peter Ward et Robert A. J. McDonald, British Columbia: Historical readings (Vancouver, Douglas \& McIntyre, 1981): 3765.

4. BADERTSCHER, Patricia M. Archaelogical investigations at EjMg-2 Childs Lake, Duck Mountain Provincial Park, Manitoba. Winnipeg, Historic Resources Branch, 1982. $\mathrm{xi}, 213 \mathrm{p}$.

5. BISHOP, Charles A. «Northeastern Indian concepts of conservation and the fur trade: a critique of Calvin Martin's thesis», Shepard Krech III, Indians, animals and the fur trade - A critique of "Keepers of the game» (Athens (Georgie), University of Georgia Press, 1981): 39-58.

6. BORDEN, Charles E. «Archaeological history of the Lower Fraser River», The Fraser's history from glaciers to early settlements (Burnaby (C.-B.), Burnaby historical society, [1981?]): 19-28.

7. BUCHNER, Anthony P. An archaelogical survey of the Winnipeg River. Winnipeg, Historic Resources Branch, 1982. v. 207 p.

8. CUMMING, Peter et Neil MICKENBERG. «Native rights in Canada: British Columbia», W. Peter Ward et Robert A.J. McDonald, British Columbia: Historical readings (Vancouver, Douglas \& McIntyre, 1981): 184-211.

9. DICKSON, Gary A. Archaelogical research in the Kame Hills Locality of Southern Indian Lake. Winnipeg, Historic Resources Branch, 1983. xii, 193 p. 
10. FISHER, Robin. «Indian control of the maritime fur trade and the northwest coast», W. Peter Ward et Robert A.J. Mcdonald, British Columbia: Historical readings (Vancouver, Douglas \& McIntyre, 1981): 96-110.

11. FISHER, Robin. «Joseph Trutch and Indian land policy», W. Peter Ward et Robert A.J. McDonald, British Columbia: Historical readings (Vancouver, Douglas \& McIntyre, 1981): 154-183.

12. FISHER, Robin. «Missions to the Indians of British Columbia», W. Peter Ward et Robert A.J. McDonald, British Columbia: Historical readings (Vancouver, Douglas \& McIntyre, 1981): 113-126.

13. FREEMAN, Milton N.R. «Persistence and change: the cultural dimension», Morris Zaslow, Un siècle des îles arctiques du Canada / 1880-1980 / A century of Canada's arctic islands (S.L., La société royale du Canada, 1981): 257-266.

14. FREEMAN, Minnie Aodla. «Ikumaaluminik - Living in two hells», Morris Zaslow, Un siècle des îles arctiques du Canada / 1880-1980 / A century of Canada's arctic islands (S.L., La société royale du Canada, 1981): 267-274.

15. ITTINUAR, Peter. «Inuit participation in politics», Morris Zaslow, Un siècle des îles arctiques du Canada / 1880-1980 / A century of Canada's arctic islands (S.L., La société royale du Canada, 1981): 291-298.

16. JAMIESON, Kathleen. Native women in Canada: a selected bibliography. Ottawa, Social science and Humanities Research Council of Canada, [1983]. 49 p.

17. JENNESS, Diamond. «The Indian's interpretation of man and nature», R. Douglas Francis et Donald B. Smith, Readings in Canadian history - Pre-confederation (Toronto, Holt, Rinehart and Winston, 1982): 44-49.

18. KOOYMAN, Brian Patrick. Metis faunal remains and variables in archaelogical butchering pattern analysis. Thèse de M.A. Université de Calgary, 1981.

19. KRECH, Shepard III. « «Throwing bad medicine»: sorcerry, disease, and the fur trade among the Kutchin and other northern Athapaskans», Shepard Krech III, Indians, animals, and the fur trade - A critique of «Keepers of the game» (Athens (Georgie), University of Georgia Press, 1981): 73-108.

20. LENNOX, Paul Anthony. The Bruner-Colasanti site: an early site woodland component, Essex County, Ontario. Ottawa: National Museum of Man, National Museums of Canada, 1982. xi, $178 \mathrm{p}$.

21. MARTIN, Calvin. «The war between Indians and animals», Shepard Krech III, Indians, animals, and the fur trade - A critique of "Keepers of the game» (Athens (Georgie), University of Georgia Press, 1981): 11-18.

22. MOLYNEAUX, Brian. The study of prehistoric sacred places: evidence from Lower Manitou Lake. Toronto, Royal Ontario Museum, 1983. 8 p.

23. MORANTZ, Toby Elaine. An ethnohistoric study of eastern James Bay Cree social organization, 1700-1850. Ottawa, National Museums of Canada, 1983. x, 199 p.

24. MORRISON, David A. Thule culture in western Coronation Gulf, N.W.T. Ottawa, National Museum of Man, National Museums of Canada. 1983. xix, $366 \mathrm{p}$.

25. NASMITH, Carol Louise, The Kirche site: a late prehistoric Huron village in the upper Trent Valley. Thèse de M.A., Université McMaster, 1981.

26. PAGE, Daniel H. Heritage of the North American Indian people: some suggestions emphasizing the eastern woodlands. Ottawa, Borealis Press, 1982. $176 \mathrm{p}$.

27. PENDERGAST, James F. The Glenbrook village site: a late St. Lawrence Iroquoian component in Glengarry County, Ontario. Ottawa: National Museums of Canada, 1981. $\mathrm{xi}, 196 \mathrm{p}$.

28. RAY, Arthur J. «Fur trade history as an aspect of native history», R. Douglas et Donald B. Smith, Readings in Canadian history-Pre-confederation (Toronto, Holt, Rinehart and Winston, 1982): 149-160.

29. ROSS, W. Gillies. «Whaling, Inuit, and arctic islands», Morris Zaslow, Un siècle des îles arctiques du Canada / 1880-1980 / A century of Canada's arctic islands (S.L., La société royale du Canada, 1981): 33-50. 
30. ROUSSEAU, Jacques et George W. BROWN. «The Indians of Northeastern North America», R. Douglas et Donald B. Smith, Readings in Canadian history - Pre-confederation (Toronto, Holt, Rinehart and Winston, 1982): 2-14.

31. SCHLEDERMANN, Peter. «Inuit prehistory and archaeology», Morris Zaslow, Un siècle des îles arctiques du Canada / 1880-1980 / A century of Canada's arctic islands (S.L., La société royale du Canada, 1981): 245-256.

32. SIGGNER, Andrew J. et Chantal LOCATELLI. Aperçu de la situation démographique, sociale et économique de la population indienne inscrite de la Colombie-britannique. Ottawa, Ministère des affaires indiennes et du nord, 1983. ix, 46 p.

33. SNOW, Dean R. «Keepers of the game» and the nature of explanation», Shepard Krech III, Indians, animals and the fur trade - A critique of "Keepers of the game» (Athens (Georgie), University of Georgia Press, 1981): 59-71.

34. STEVENSON, Marc. Étude préliminaire sur les sites préhistoriques dans le parc national de Kluane. 1978 et 1980. Coll. «Bulletin de recherches» no 177. Ottawa, Parcs Canada, 1980. 22 p.

35. STURTEVAN, William C. «Animals and disease in indian belief», Shepard Krech III, Indians, animals, and the fur trade - A critique of "Keepers of the game» (Athens (Georgie), University of Georgia Press, 1981): 176-188.

36. TRIGGER, Bruce Graham. «Ontario native people and the epidemics of 1634-1640», Shepard Krech III, Indians, animals, and the fur trade - A critique of "Keepers of the game» (Athens (Georgie), University of Georgia Press, 1981): 19-38.

37. TRIGGER, Bruce Graham. «The French presence in Huronia: the structure of franco-huron relations in the first half of the seventeenth century», R. Douglas Francis et Donald B. Smith, Readings in Canadian history - Pre-confederation (Toronto, Holt, Rinehart and Winston, 1982): 14-44.

38. UPTON, Leslie F.S. «Contact and conflict on the Atlantic and Pacific coasts of Canada», R. Douglas Francis et Donald B. Smith, Readings in Canadian history - Pre-confederation (Toronto, Holt, Rinehart and Winston, 1982): 426-438.

39. USHER, Jean. «Duncan of Metlakatla: the victorian origins of a model indian community», W. Peter Ward et Robert A.J. Mcdonald, British Columbia: Historical readings (Vancouver, Douglas \& McIntyre, 1981): 127-153.

40. WONDERS, William C. «Unrolling the map of Canada"s arctic», Morris Zaslow, Un siècle des îles arctiques du Canada / 1880-1980 / A century of Canada's arctic islands (S.L., La société royale du Canada, 1981): 1-14.

\section{II — LA COLONISATION FRANÇAISE EN AMÉRIQUE}

\section{1- HISTOIRE GÉNÉRALE}

41. JAENEN, Cornelius J. «Canada during the French regime», D.A. Muise, A reader's guide to Canadian history - 2 Beginnings to Confederation (Toronto, University of Toronto Press, 1982): 3-44.

42. KRUEGER, Ralph R. «A geographical perspective: the setting and the settlement», William Metcalfe, Understanding Canada. A multidisciplinary introduction to Canadian studies (New York, New York University Press, 1982): 11-79.

43. LANDE, Lawrence Montague. The political economy of New France: as developed by John Law, Compagnie des Indes \& the French-Canadian traders: a bibliography. [Montréal?], s.n., 1983. xii, 98 p.

44. McCANN, L.D. A geography of Canada. Heartland and hinterland. Scarborough, Prentice Hall, 1982. x, $500 \mathrm{p}$.

45. MUISE, D.A. A reader's guide to Canadian History - 1 Beginnings to Confederation. Toronto, University of Toronto Press, 1982. xv, $253 \mathrm{p}$.

46. OLIVIER, Réjean. Bibliophile et homme de culture, Philippe Boucher, curé en NouvelleFrance: sa vie et sa bibliothèque: inventaire sommaire. L'Assomption (Québec), Collège de l'Assomption, Bibliothèque, 1981. $20 \mathrm{p}$. 
47. PENTLAND, Harry Clare. Labour and capital in Canada, 1650-1860. Toronto, J. Lorimer, 1981, xvii, 280 p.

48. STEELE, I.K. «Sugar or snow» R. Douglas Francis et Donald B. Smith, Readings in Canadian history - Pre-confederation (Toronto, Holt, Rinehart and Winston, 1982): 137-141. (Discussions entre la France et l'Angleterre sur le partage des colonies).

VOIR AUSSI : 40.

\section{2 - TERRE-NEUVE, L'ACADIE ET L'ÎLE ROYALE JUSQU'EN 1760}

49. ARSENEAULT, Samuel. «Place name changes in the Cartography of Acadia. The Use of the Word «Acadia» in North America between 1529 and 1763», La Société historique acadienne - Les cahiers, 14, 3 (sept. 1983): 95-103.

50. DEVEAU, J.-Alphonse. L'abbé Le Loutre et les Acadiens. Agincourt (Ont.), Société canadienne du livre, $1983.75 \mathrm{p}$.

51. McNEILL, John Robert. Theory and practice in the Bourbon Empires of the Atlantic: the roles of Louisbourg and Havana, 1713-1763. Thèse de Ph.D., Duke University, 1981.

\section{3 - LE CANADA JUSQU'EN 1760}

52. ALLAIRE, Gratien. Les engagés de la fourrure, 1701-1745: une étude de leur motivation. Thèse de Ph.D., Université Concordia, 1981.

53. ALMAZAN, Vincent. Français et Canadiens dans la région du Détroit aux XVII et XVIII siècles. Coll. «Documents historiques» no 69. Sudbury, Société historique du NouvelOntario, 1979. $67 \mathrm{p}$.

54. BOGLIONI, Pierre et Benoît LACROIX. Les pèlerinages au Québec. Québec, Les Presses de l'Université Laval, 1981. 163 p.

55. BOUCHARD, René et al. Itinéraire toponymique du chemin du Roy, Québec-Montréal. Québec, Gouvernement du Québec, Commission de toponymie, 1981.v, 89 p.

56. CAMERON, William J. A bibliography in short-title catalog form of eighteenth century editions of Lettres édifiantes, collected letters from Jesuit missionaries. [London, University of Western Ontario], 1982. ii, $23 \mathrm{p}$.

57. CAMERON, William J. A bibliography in short-title catalog form of eighteenth century editions of the writings of Louis Armand de Lom D'Arce, Baron de Lahontan. [London, The University of Western Ontario], 1982. ii, $14 \mathrm{p}$.

58. CAMERON, William. A bibliography in short-title catalog form of Jesuit relations, printed accounts of events in Canada, 1632-73, sent by Jesuit missionaries to France. [London, University of Western Ontario], 1982. ii, $26 \mathrm{p}$.

59. CAMERON, William J. A bibliography in short-title catalog form of seventeenth and eighteenth century editions of the writings of Louis Hennepin, Recollet explorer and missionary. [London, University of Western Ontario], 1982. 15 p.

60. CHARBONNEAU, Fernande. Marguerite Bourgeoys: traits spirituels et mystiques. Montréal, Éditions Paulines, 1983. 126 p.

61. CLOUTIER, Nicole. «La peinture votive à Sainte-Anne-de-Beaupré», Benoit Lacroix et Jean Simard, Religion populaire - Religion de clercs? (Québec, Institut québécois de recherche sur la culture, 1984): 149-179.

62. CROWLEY, Terence. «Thunder Gusts»: Popular disturbances in Early French-Canada», R. Douglas Francis et Donald B. Smith, Readings in Canadian history - Pre-confederation (Toronto, Holt, Rinehart and Winston, 1982): 67-88.

63. DESLOGES, Yvon. «La corvée militaire à Québec au XVIII ${ }^{\mathrm{e}}$ siècle», Histoire sociale । Social history, 15, 30 (nov. 1982): 333-356.

64. DICKINSON, John Alexander. Justice et justiciables: la procédure civile à la Prévôté de Québec, 1667-1759. Québec, Presses de l'Université Laval, 1982. viii, 289 p.

65. DUMAS, Silvio. «L'ermite de Trois-Pistoles. Les déboires d'un janséniste en NouvelleFrance», L'Écho des Basques, 4,1 (déc. 1983): 40-51. (Texte d'une conférence de 1943). 
66. DUPONT, Jean-Claude. «Mentalité religieuse des gens de métiers traditionnels», Benoit Lacroix et Jean Simard, Religion populaire - Religion de clercs? (Québec, Institut québécois de recherche sur la culture, 1984): 257-265.

67. DUVAL, Monique. Découvrir Québec. Québec, Le Soleil, 1983. 117 p.

68. ECCLES, W.J. «Society and the frontier», R. Douglas Francis et Donald B. Smith, Readings in Canadian history - Pre-confederation (Toronto, Holt, Rinehart and Winston, 1982): 51-67.

69. ECCLES, W.J. «The french forces in North America during the seven years' war», R. Douglas Francis et Donald B. Smith, Readings in Canadian history - Pre-confederation (Toronto, Holt, Rinehart and Winston, 1982): 115-127.

70. GÉLINAS, Cyrille. Le rôle du fort de Chambly dans le développement de la NouvelleFrance de 1665 à 1760. Ottawa, Direction des lieux et des parcs historiques nationaux, Parcs Canada. 1983. 79 p.

71. GRENIER, Cécile et Joshua WOLFE. Guide Montréal: un guide architectural et historique. [Montréal], Libre expression, 1983. 338 p.

72. HURTUBISE, Pierre. «La religiosité populaire en Nouvelle-France», Benoit Lacroix et Jean Simard, Religion populaire - Religion de clercs? (Québec, Institut québécois de recherche sur la culture, 1984): 53-64.

73. LA HONTAN, Louis Armand de. Nouveaux voyages en Amérique septentrionale. Montréal, L'Hexagone/Minerve, 1983. 346 p.

74. LACHANCE, André, «Women and crime in Canada in the early eighteenth century, 17121759», Louis A. Knafla, Crime and Criminal justice in Europe and Canada (Waterloo, Wilfrid Laurier University Press, 1981): 157-177.

75. LOCAS, Marc. Sainte-Geneviève - ses quatre saisons. s.1., s.n., [1981?]. 174 p. (Montréal).

76. MIMEAULT, Mario. «La déportation de Gaspé. L'établissement de Pierre Révol à Gaspé 1756-1758», Gaspésie, 21, 3 (83) (sept. 1983): 40-49.

77. POIRIER, Jean. Éléments de bibliographie: est du Québec. [Québec], Ministère de l'Éducation, Direction régionale du Bas-Saint-Laurent-Gaspésie, 1981. 86 p.

78. RIOUX, Élisée. «Une amusante histoire de baleine», L'Écho des Basques, 4, 1 (déc. 1983): 11-13. (Capture d'une baleine à Trois-Pistoles vers 1750).

79. RIOUX, Emmanuel. «Sur les traces de Jacques Cartier», L'Écho des Basques, 4, 1 (déc. 1983): 2-10.

80. STACEY, C.P. «The British forces in North America during the Seven years' war», R. Douglas Francis et Donald B. Smith, Readings in Canadian history - Pre-confederation (Toronto, Holt, Rinehart and Winston, 1982): 127-137.

81. SEALY, D. Bruce. «Origin of the metis», R. Douglas Francis et Donald B. Smith, Readings in Canadian history - Pre-confederation (Toronto, Holt, Rinehart and Winston, 1982): 160-167.

82. THIBAULT, Réjane. «La vie intellectuelle et la société en Nouvelle-France», Asticou. Revue d' histoire de l'Outaouais, 29 (déc. 1983): 10-30.

83. VOYER, Louise. Églises disparues. Avec la collaboration de André Laberge [et al.]. [Montréal], Libre Expression, 1981. 168 p.

84. WELLS, Garron. The development of trade along the north west coast of Hudson Bay 1717-1790. Thèse de M.A., Université du Manitoba, 1982.

85. ZIBARA, Leila. Deux récits de voyage en Nouvelle-France au dix-septième siècle. Thèse de M.A., Université Dalhousie, 1982.

VOIR AUSSI: 1; 2; 23; 28; 36; 37. 


\section{III - LA COLONISATION ANGLAISE EN AMÉRIQUE 1 - HISTOIRE GÉNÉRALE}

86. BERGER, Carl. Science, God and Nature in Victorian Canada. Toronto, University of Toronto Press, 1983, 92 p.

87. BUCKNER, Phillip. «Britain and British North America before Confederation», D.A. Muise, A reader's guide to Canadian history -2 Beginnings to Confederation (Toronto, University of Toronto Press, 1982): 193-236.

88. BUMSTED, J.M. The Scots in Canada. Ottawa, Canadian Historical Association, 1982. $19 \mathrm{p}$.

89. BURNS, R.M. «The British parliamentary system and Canadian federalism», W.R. Lederman, Continuing canadian constitutional dilemmas - Essays on the constitutional history [...] (Toronto), Butterworths, 1981): 47-62.

90. CHAPMAN, Terry. «The measurement of crime in nineteenth century Canada; some methodological and philosophical problems», Louis A. Knafla, Crime and Criminal justice in Europe and Canada (Waterloo, Wilfrid Laurier University Press, 1981): 147-155.

91. CON, Harry et al. From China to Canada: a history of the Chinese communities in Canada. Toronto, McClelland and Stewart, 1982. viii, 369 p.

92. CREIGHTON, Donald G. «The economic background of the rebellions of eighteen thirtyseven», R. Douglas Francis et Donald B. Smith, Readings in Canadian history - Preconfederation (Toronto, Holt, Rinehart and Winston, 1982): 321-332.

93. FLETCHER, Frederick J. et Daphne F. GOTTLIEB. «The mass media and the political process", Michael S. Whittington et Glen Williams, Canadian politics in the $1980 \mathrm{~s}$ (Toronto, Methuen, 1981): 142-166.

94. GUTKIN, Harry. The Jewish Canadians. Scarborough (Ont.), Nelson Canada, 1983. 72 p.

95. KAPLAN, Harold. Reform, Planning, and City Politics: Montreal, Winnipeg, and Toronto. Toronto, University of Toronto Press, 1982. xi, 775 p.

96. KALMAN, Maxwell M. et Harold KALMAN. Maquette du premier édifice central du parlement / A model of the original centre block of the parliament buildings. Ottawa, Archives publiques du Canada, [1983?]. (Ottawa). 14 p.

97. LONGLEY, Ronald Stewart. Sir Francis Hincks: a study of Canadian politics, railways, and finance in the nineteenth century. New York, Arno Press, 1981. vi, $480 \mathrm{p}$.

98. MONET, Jacques. «The 1840s», R. Douglas Francis et Donald B. Smith, Readings in Canadian history - Pre-confederation (Toronto, Holt, Rinehart and Winston, 1982): 341-360.

99. MUISE, D.A. «Confederation», D.A. Muise, A reader's guide to Canadian history - 2 Beginnings to Confederation (Toronto, University of Toronto Press, 1982): 237-248.

100. MYERS, Gustavus. «The hudson's bay company», R. Douglas Francis et Donald B. Smith, Readings in Canadian history - Pre-Confederation (Toronto, Holt, Rinehart and Winston, 1982): 143-149.

101. POMFRET, Richard. The economic development of Canada. Toronto, Methuen, 1981. viii, $215 \mathrm{p}$.

102. REDMOND, Gerald. The sporting Scots of nineteenth-century Canada. Rutheford (N.J.), Fairleigh Dickinson University Press; Londres, Toronto, Associated University Press, 1982, 347 p.

103. SCHNELL, R.L. «Childhood rescued and restrained in English Canada», Patricia T. Rooke et R.L. Schnell, Studies in childhood history - A canadian perspective (Calgary, Detselig, 1982): 204-212.

104. SÉGUIN, Maurice. «A disaster», R. Douglas Francis et Donald B. Smith, Readings in Canadian history - Pre-confederation (Toronto, Holt, Rinehart and Winston, 1982): 334-341. (Gouvernement de l'union).

105. SIEGEL, Arthur. Politics and the Media in Canada. Toronto, McGraw-Hill Ryerson, 1983. xii, $258 \mathrm{p}$.

106. SILVERMAN, Jason Howard. Unwelcome guest American fugitive slaves in Canada, 1830-1860. Thèse de Ph.D., University of Kentucky, 1981. 
107. SKEOCH, Alan. United Empire Loyalists and the American Revolution, Toronto, Grolier Ltd, $1981.96 \mathrm{p}$.

108. SKEOCH, Alan E. «Developments in plowing technology in nineteenth-century Canada», Donald H. Akenson, Canadian papers in rural history - Volume III (Gananoque, Langdale press, 1982): 156-177.

109. STANLEY, George F.G. «Act or pact: another look at confederation» R. Douglas Francis et Donald B. Smith. Readings in Canadian history - Pre-confederation (Toronto, Holt, Rinehart and Winston, 1982): 503-525.

110. «The independance of the judiciary», W.R. Lederman, Continuing canadian constitutional dilemmas - Essays on the constitutional history [...] (Toronto, Butterworths, 1981): 109-174.

111. "The nature of confederation», R. Douglas Francis et Donald B. Smith, Readings in Canadian history - Pre-confederation (Toronto, Holt, Rinehart and Winston, 1982): 491502. (Extrait du rapport de la commission Rowell-Sirois).

112. VERDUN-JONES, Simon N. «Not guilty by reason of insanity»: The historical roots of the Canadian insanity defence, 1843-1920», Louis A. Knafla, Crime and Criminal justice in Europe and Canada (Waterloo, Wilfrid Laurier University Press, 1981): 179218.

113. VINCENT, Élizabeth. Bibliographie choisie et commentée applicable à l'étude des techniques de construction du génie militaire en Amérique du Nord britannique, au XIX ${ }^{e}$ siècle. Coll. «Bulletin de recherches» no 190. [Ottawa], Parcs Canada, 1983. 22 p.

114. WHYTE, J.D. «The extension of governmental institutions and legal systems to British North America in the colonial period», W.R. Lederman, Continuing canadian constitutional dilemmas - Essays on the constitutional history [...] (Toronto, Butterworths, 1981): 63-80.

VOIR AUSSI: $28 ; 42 ; 45 ; 47 ; 80$.

\section{2 -- LES PROVINCES DE L'ATLANTIQUE}

115. BAILEY, Alfred G. "The basis and persistence of opposition to Confederation in New Brunswick», R. Douglas Francis et Donald B. Smith, Readings in Canadian history - Pre-confederation (Toronto, Holt, Rinehart and Winston, 1982): 455-474.

116. BAKER, Melvin. The government of St. John's Newfoundland, 1800-1921. Thèse de Ph.D., University of Western Ontario, 1981.

117. BREBNER, John Bartlet. «Profits and pains of neutrality», R. Douglas Francis et Donald B. Smith, Readings in Canadian history - Pre-confederation (Toronto, Holt, Rinehart and Winston, 1982): 252-270.

118. BUGGEY, Susan. Churchmen and dissenters: Religious toleration in Nova Scotia, 17581835. Thèse de M.A., Université Dalhousie, 1981.

119. DAIGLE, Jean. "The Acadians: a people in search of a country», Raymond Breton et Pierre Savard, The Quebec and Acadian diaspora in North America (Toronto, The multicultural history society of Ontario, 1982): 1-10.

120. DUFFUS, Allan et al. Thy dwellings fair: churches of Nova Scotia. 1750-1830. Hantsport (N.-É), Lancelot Press, 1982. 189 p.

121. EATON, E.L. The history of the United Church of Canada in Windsor, Nova Scotia. S.n., $1981.48 \mathrm{p}$.

122. FISCHER, Lewis R. «Harbour and metropolis: the shipping industry of Saint John and the urban economy, 1820-1914», Lewis R. Fisher et Eric W. Sager, Merchant shipping and economic development in Atlantic Canada (Saint-Jean, Université Memorial, 1981): 35-53.

123. FREGAULT, Guy. «The deportation of the Acadiens, 1755-62», R. Douglas Francis et Donald B. Smith, Readings in Canadian history - Pre-confederation (Toronto, Holt, Rinehart and Winston, 1982): 111-113. 
124. GRIFFITHS, Naomi. «Decision and consequence: 1755», R. Douglas Francis et Donald B. Smith, Readings in Canadian history - Pre-confederation (Toronto, Holt, Rinehart and Winston, 1982): 100-110. (Déportation des Acadiens).

125. GRIFFITHS, Naomi. «Prologue to disaster: 1749-1755», R. Douglas Francis et Donald B. Smith, Readings in Canadian history - Pre-confederation (Toronto, Holt, Rinehart and Winston, 1982): 90-99. (Déportation des Acadiens).

126. HUTCHINSON, Roland Henry. The early Methodist connection of the Steeves family. [Wallace (N.É.)], RAGG Publisher, 1981.23 p.

127. LÉGER, Maurice A. «Centenaire du drapeau acadien - Un historique», La Société historique acadienne - Les cahiers, 14, 3 (sept. 1983): 107-157.

128. McCARTHY, Michael. The Irish in Newfoundland, 1623-1800. Saint-Jean (T.-N.), H. Cuff Publications, 1982. $62 \mathrm{p}$.

129. McLEOD, Grace. The history of the United Baptist Church at Penobsquis. [Penobsquis, N.-B., s.n.], 1981. 82, 34 p.

130. MAILLET, Marguerite. «Un peuple à rassembler (journaux et discours)», La Société historique acadienne - Les cahiers, 14, 3 (sept. 1983): 91-94.

131. MANNION, John. «The Waterford Merchants and the Irish-Newfoundland provisions trade, 1770-1820», Donald H. Akenson, Canadian papers in rural history - Volume III (Gananoque, Langdale Press, 1982): 178-203.

132. MILLMAN, Thomas R. Atlantic Canada to 1900: a history of the Anglican Church. Toronto, Anglican Book Centre, 1983. $180 \mathrm{p}$.

133. MUISE, D.A. «The Atlantic provinces», D.A. Muise, A reader's guide to Canadian history -2 Beginnings to Confederation (Toronto, University of Toronto Press, 1982): $78-122$.

134. PANTING, Gerry. «Shipping investment in the urban centres of Nova Scotia», Lewis R. Fischer et Eric W. Sager, Merchant shipping and economic development in Atlantic Canada (Saint-Jean, Université Memorial, 1981): 125-136.

135. PRATT, Robert H. The pence issues of Newfoundland, 1857-1866. [Toronto], Vincent G. Greene Philatelic Research Foundation, 1982. 192 p.

136. PRYKE, K.G. «Labour and politics: Nova Scotia at confederation», R. Douglas Francis et Donald B. Smith, Readings in Canadian history - Pre-confederation (Toronto, Holt, Rinehart and Winston, 1982): 390-407.

137. PUNCH, Terrence M. Irish Halifax: the immigrant generation 1815-1859. Halifax, International Education Centre, Saint Mary's University, 1981, 86 p.

138. PUNCH, Terrence M. Nova Scotia vital statistics from newspapers: 1769-1812. Halifax, Genealogical Committee of the Royal Nova Scotia Historical Society, 1981. 110 p.

139. ROOKE, Patricia et R.L. SCHNELL. «Guttersnipes and charity children: Nineteenth century child rescue in the Atlantic provinces», Patricia T. Rooke et R.L. Schnell, Studies in childhood history - A canadian perspective (Calgary, Detselig, 1982): 82-104.

140. SAGER, Eric W., Lewis R. FISCHER et Rosemary E. OMMER. «Landward and seaward opportunities in Canada's age of sail», Lewis R. Fischer et Eric W. Sager, Merchant shipping and economic development in Atlantic Canada (St. John's Memorial University, 1981): 9-31.

141. STANLEY, George F.G. «Ce prêtre difficile - Commentaires sur les activités du Père Georges-Antoine Belcourt», La Société historique acadienne - Les cahiers, 14, 2 (juin 1983): 39-58.

142. WHITELAW, William Menzies. «The Atlantic provinces and their neighbours», R. Douglas Francis et Donald B. Smith, Readings in Canadian history - Pre-confederation (Toronto, Holt, Rinehart and Winston, 1982): 407-426. 


\section{3 - LE QUÉBEC ET LE BAS-CANADA ET LE CANADA-UNI}

143. BEAULIEU, J.-François, «Le diable «constructeur d'église» », L'Écho des Basques, 4, 1 (déc. 1983): 36-37. (La construction de l'église de Trois-Pistoles).

144. BERNIER, Gérald. «Le parti patriote (1827-1838)», Vincent Lemieux, Personnel et partis politiques au Québec - Aspects historiques (Montréal, Boréal Express, 1982): 207228.

145. BÉRUBÉ, Laurent. «Une oeuvre d'art dans l'église de Trois-Pistoles», L'Écho des Basques, 4, 1 (déc. 1983): 14-15. (Collection de l'abbé Desjardins).

146. BOILY, Robert. «Les partis politiques québécois - perspectives historiques», Vincent Lemieux, Personnel et partis politiques au Québec - Aspects historiques (Montréal, Boréal Express, 1982): 27-68.

147. BONENFANT, Jean-Charles. «The French Canadians and the birth of Confederation», $R$. Douglas Francis et Donald B. Smith, Readings in Canadian history - Pre-confederation (Toronto, Holt, Rinehart and Winston, 1982): 474-489.

148. BONENFANT, Joseph. "Crémazie et Nelligan sous le signe du romantisme», Réjean Robidoux et Paul Wyczynski, Crémazie et Nelligan (Montréal, Fides, 1981): 125-131.

149. BOULET, Fernand. Usages et coutumes au Collège de L'Assomption de 1832 à 1840 . Joliette (Québec), R. Olivier, 1982, 38 p.

150. BOURASSA, André-G. «Crémazie et Nelligan au pied de la lettre», Réjean Robidoux et Paul Wyczynski, Crémazie et Nelligan (Montréal, Fides, 1981): 132-140.

151. BRAULT, Pierre. Les fêtes de l'Acadie 1782-1982. Saint-Jean-sur-Richelieu (Québec) Éditions Mille Roches, 1983, 63 p.

152. BRUNET, Michel. «French Canada and the early decades of British rule, 1760-1791», R. Douglas Francis et Donald B. Smith, Readings in Canadian history-Pre-confederation (Toronto, Holt, Rinehart and Winston, 1982): 239-252.

153. CARAFFE, Marc de. La difficile naissance d' un système d'éducation publique au Québec (1801-1876). Coll. «Bulletin de recherches» no 188. [Ottawa], Parcs Canada, 1983, $14 \mathrm{p}$.

154. CHIASSON, Anselme. Les îles de la Madeleine: vie matérielle et sociale de l'an premier. [Montréal], Leméac, 1981. 269 p.

155. CLICHE, Marie-Aimée. «L'évolution des clauses religieuses traditionnelles dans les testaments de la région de Québec au XIX ${ }^{\mathrm{e}}$ siècle», Benoit Lacroix et Jean Simard, Religion populaire - Religion de Clercs? (Québec, Institut québécois de recherche sur la culture, 1984): 365-388.

156. DECHAMPLAIN, A.-A. «Seigneurie de Métis», L'Estuaire généalogique, 3, 9 (janv. 1984).

157. DEVOST, Alain. L'imprimerie au Québec. Québec, Commission de la santé et de la sécurité du travail, 1982. 366 p.

158. DUMAS, Paul. «Histoire de coq», L'Écho des Basques, 4, 1 (déc. 1983): 52. (Le coq de l'église de Trois-Pistoles).

159. FIOLA, Léo. «Familles de Cloridorme, 1838-1983», L'Estuaire généalogique, 3, 9 (janv. 1984): 175.

160. GAGNON, Serge. «Morales d'aujourd'hui, morales d'hier», Benoit Lacroix et Jean Simard, Religion populaire - Religion de clercs? (Québec, Institut québécois de recherche sur la culture, 1984): 79-94.

161. HARE, John E. «Perspectives sociologiques: Octave Crémazie et la poésie dans une société de consommation», Réjean Robidoux et Paul Wyczynski, Crémazie et Nelligan (Montréal, Fides 1981): 155-161.

162. HAY, Douglas. «The meanings of the criminal law in Quebec, 1764-1774», Louis A. Knafla, Crime and Criminal justice in Europe and Canada (Waterloo, Wilfrid Laurier University Press, 1981): 77-110.

163. HAYNE, David-M. «Crémazie et le poème de circonstance au Canada», Réjean Robidoux et Paul Wycynski, Crémazie et Nelligan (Montréal, Fides, 1981): 43-48.

164. HAYNE, David-M. «Emigration and colonization: twin themes in Nineteenth-century French Canadian literature», Raymond Breton et Pierre Savard, The Quebec and Acadian 
diaspora in North America (Toronto, The multicultural history society of Ontario, 1982): 11-22.

165. IGARTUA, José. «A change in climate: the conquest and the «marchands» of Montreal», R. Douglas Francis et Donald B. Smith, Readings in Canadian history-Pre-confederation (Toronto, Holt, Rinehart and Winston, 1982): 221-237.

166. LAJEUNESSE, Marcel. Les Sulpiciens et la vie culturelle à Montréal au XIXe siècle. Montréal, Fides, 1982, 278 p.

167. LAPOINTE, Raoul. «Trois témoins des temps héroïques», Saguenayensia, 25, 3 (juill.sept. 1983): 59-72. (François Pilote, Lucien Otis, Louis-A. Martel).

168. LEMIEUX, Denise. «La religion populaire et les classes sociales - Quelques réflexions», Benoit Lacroix et Jean Simard, Religion populaire - Religion de clercs? (Québec, Institut québécois de recherche sur la culture, 1984): 297-303.

169. LESSARD, Claude. Guide des fonds d'archives conservés à l'Université du Québec à Trois-Rivières. Trois-Rivières, Centre de documentation en études québécoises, Université du Québec à Trois-Rivières, 1981. [87] p.

170. McINNIS, R. M. «A reconsideration of the state of agriculture in Lower Canada in the first half of the nineteenth century», Donald H. Akenson, Canadian papers in rural history - Volume III (Gananoque, Langdale Press, 1982): 9-49.

171. MAJOR, Jean-Louis. «Perspectives esthétiques: fantasme d'écrivain et figure du texte», Réjean Robidoux et Paul Wyczynski, Crémazie et Nelligan (Montréal, Fides, 1981): 167-175.

172. MARTIN, Nicole. La maison du bedeau: L'Acadie 1831. Saint-Jean-sur-Richelieu (Québec), Éditions Mille Roches, [1983?]. 71 p.

173. MICHON, Jacques. «Perspectives sémiotiques: sémiotique du texte poétique et histoire littéraire», Réjean Robidoux et Paul Wyczynski, Crémazie et Nelligan (Montréal, Fides, 1981): 162-166.

174. MURRAY, James. «General Murray's report of the state of the government of Quebec in Canada June 5th, 1762», R. Douglas Francis et Donald B. Smith, Readings in Canadian history - Pre-confederation (Toronto, Holt, Rinehart and Winston, 1982): 169. 200.

175. NEPVEU, Philippe. «Crémazie et Nelligan: l'exil comme métaphore», Réjean Robidoux et Paul Wyczynski, Crémazie et Nelligan (Montréal, Fides, 1981): 132-140.

176. O'GALLAGHER, Marianna. Saint Brigid's, Quebec: the Irish care for their people, 1856 to 1981. Quebec, Carraig Books, 1981. $80 \mathrm{p}$.

177. OUELLET, Fernand. «Québec, 1760-1867», D.A. Muise, A reader's guide to Canadian history - 2 Beginnings to Confederation (Toronto, University of Toronto Press, 1982): 45-76.

178. OUELLET, Fernand. «The Birth of French-Canadian nationalism», R. Douglas Francis et Donald B. Smith, Readings in Canadian history - Pre-confederation (Toronto, Holt, Rinehart and Winston, 1982): 213-220.

179. OUELLET, Fernand. «The insurrections», R. Douglas Francis et Donald B. Smith, Readings in Canadian history - Pre-confederation (Toronto, Holt, Rinehart and Winston, 1982): 308-321.

180. OUELLET, Fernand. «The legacy of New France restored favour», R. Douglas Francis et Donald B. Smith, Readings in Canadian history - Pre-conferation (Toronto, Holt, Rinehart and Winston, 1982): 201-212.

181. RIOUX, Cybèle. «Les six cimetières de Trois-Pistoles», L'Écho des Basques, 4, 1 (déc. 1983): 32-33.

182. ROBERT, Lucie. «Octave Crémazie critique littéraire», Réjean Robidoux et Paul Wyzcynski, Crémazie et Nelligan (Montréal, Fides, 1981): 65-72.

183. ROBIDOUX, Réjean. «Le poète: «Echo sonore» ou créateur de réalité», Réjean Robidoux et Paul Wyczynski, Crémazie et Nelligan (Montréal, Fides, 1981): 119-124. (Octave Crémazie).

184. ROY, Jean-Louis. «L'usine du grand sault. Une inaltérable déception», Gaspésie, 21, 3 (83) (sept. 1983): 8-15. 
185. ROY, Jean-Louis. «La librairie Crémazie», Réjean Robidoux et Paul Wyczynski, Crémazie et Nelligan (Montréal, Fides, 1981): 11-42.

186. RUDDEL, David-Thiery. Le protestantisme français au Québec, 1840-1919: «images» et témoignages. Ottawa, Musées nationaux du Canada, 1983. viii, 76p.

187. SENIOR, Elinor Kyte. Roots of the Canadian army; Montreal district, 1846-1870. Montréal, Historical Publications, the Society of the Montreal Military \& Maritimes Museum / La Société du Musée militaire et maritime de Montréal, 1981. 125p.

188. SIMARD, Marc. Papineau et les patriotes de 1837. Agincourt (Ont.), Société canadienne du livre, 1983. $71 \mathrm{p}$.

189. TULCHINSKY, Gérald. "Immigration and Charity in the Montreal Jewish Community before 1890», Histoire sociale / Social history, 16, 32 (nov. 1983): 359-380.

190. VOISINE, Nive. «Mouvements de tempérance et religion populaire», Benoit Lacroix et Jean Simard, Religion populaire - Religion de clercs? (Québec, Institut québécois de recherche sur la culture, 1984): 65-78.

191. WHITE, Ruth L. Louis-Joseph Papineau et Lamennais: le chef des Patriotes canadiens à Paris, 1839-1845 avec correspondance et documents inédits. Montréal, Hurtubise HMH, 1983. 643p.

192. YOUNG, Brian Jefferry. George-Étienne Cartier bourgeois montréalais. Montréal, Boréal Express, 1982. $243 \mathrm{p}$.

VOIR AUSSI: $23 ; 54 ; 55 ; 63 ; 66 ; 67 ; 71 ; 75 ; 77 ; 83$.

\section{4 - LE HAUT-CANADA ET LE CANADA-UNI}

193. AKENSON, Donald H. «Ontario: Whatever happened to the Irish», Donald H. Akenson, Canadian papers in rural history - Volume III (Gananoque, Langdale press, 1982): 204-256.

194. ARMITAGE, Andrew D. Owen Sound: steamboat days. Erin (Ont.), Boston Mills Press, $1981.88 \mathrm{p}$.

195. ARMSTRONG, Frederick $\mathrm{H}$. «Ethnicity in the formation of the family compact: a case study in the growth of the canadian establishment», Jorgen Dahlie et Tissa Fernando, Ethnicity, Power and politics in Canada (Toronto, Methuen, 1981): 22-37.

196. BESZEDITS, Stephen. Eminent Toronto architects of the past: their lives and works. Toronto, B \& L Information Services, 1983. $128 \mathrm{p}$.

197. BLOCH, Gerald. «Robert Gourlay's vision of agrarian reform», Donald H. Akenson, Canadian papers in rural history - Volume III (Gananoque, Langdale press, 1982): 110-128.

198. CADIEUX, Lorenzo. Les Robes noires à l'Île du Manitou, 1853-1870. Coll. «Documents historiques» no 75. Sudbury, Société historique du Nouvel-Ontario, 1982. 74 p.

199. CHOQUETTE, Robert. «The role of the church in French Ontario», Raymond Breton et Pierre Savard, The Quebec and Acadian diaspora in North America (Toronto, The multicultural history society of Ontario, 1982): 159-166.

200. CLARKE, John. «The activity of an early canadian land speculator in Essex county, Ontario; would the real John Askin please stand up?», Donald H. Akenson, Canadian papers in rural history - Volume III (Gananoque, Langdale Press, 1982): 84-109.

201. CURTIS, Bruce. «Schoolbooks and the Myth of Curricular Republicanism: The State and the Curriculum in Canada West, 1820-1850», Histoire sociale / Social history, 16, 32 (nov. 1983): 305-329.

202. DARROCH, A. Gordon. «Occupational Structure, Assessed Wealth and Homeowning during Toronto's Early Industrialization, 1861-1899», Histoire sociale / Social History, 16, 32 (nov. 1983): 381-410.

203. FARR, Dorothy M. The Rideau Canal: early Canadian views. Kingston (Ont.), Agnes Etherington Art Centre, Queen's University, 1982.16 p.

204. GLAZEBROOK, G.P. de T. The Church of England in Upper Canada. 1785-1867. Toronto, G.P. de T. Glazebrook, 1982. iv, 172 p. 
205. GOHEEN, Peter G. «Currents of change in Toronto, 1850-1900», R. Douglas et Donald B. Smith, Readings in Canadian history - Post-confederation (Toronto, Holt, Rinehart and Winston, 1982): 217-247.

206. HILL, Hamnett Pinhey. The genesis of our capital. Ottawa, Historical Society of Ottawa - Société historique d'Ottawa, 1982. $7 \mathrm{p}$

207. HOCKING, Anthony. L'Ontario. Toronto, McGraw-Hill Ryerson, 1981. 95 p.

208. Illustrated historical atlas - the county of Perth, Ont., including Stratford \& St. Marys. Stratford (Ont.), Cumming Publishers, 1982. $144 \mathrm{p}$.

209. JOHNSON, J.K. «Upper Canada», D.A. Muise, A reader's guide to Canadian history2 Beginnings to Confederation (Toronto, University of Toronto Press, 1982): 123-160.

210. KOZICZ, Norah Navin. A living village: a guide to Wentworth heritage village. Ottawa, Steel Rail Educational Pub., 1982. 60 p.

211. LOVE, James H. «Cultural Survival and Social Control: The Development of a Curriculum for Upper Canada's Common Schools in 1846», Histoire sociale / Social history, 15, 30 (nov. 1982): 357-382.

212. Mc CALLA, Douglas. «The «Loyalist» Economy of Upper Canada, 1784-1806», Histoire sociale / Social history, 16, 32 (nov. 1983): 279-304.

213. MARTYN, Lucy Booth. The face of early Toronto: an archival record, 1797-1936. Sutton West (Ont.), Paget Press, 1982. 157 p.

214. MILLS, David. The concept of loyalty in Upper Canada 1815-1850. Thèse de Ph.D., Université Carleton, 1982.

215. NORRIS, Darrell A. et Victor KONRAD. «Time, content, and house type validation: Euphrasia township, Ontario», Donald H. Akenson, Canadian papers in rural history - Volume III (Gananoque, Langdale press, 1982): 50-83.

216. OSBORNE, Brian S. «The Artist as Historical Commentator: Thomas Burrowes and the Rideau Canal», Archivaria, 17 (hiv. 1983-1984): 41-59.

217. RASPORICH, Anthony W. «William Lyon Mackenzie», R. Douglas Francis et Donald B. Smith, Readings in Canadian history - Pre-confederation (Toronto, Holt, Rinehart and Winston, 1982): 296-307.

218. REDISH, Angela. The economic crisis of 1837-39 in Upper Canada: case study of a temporary suspension of specie payments. Vancouver, Dept. of Economics, the University of British Columbia, 1983. $34 \mathrm{p}$.

219. REDISH, Angela. The optimal supply of bank money: Upper Canada's experience on and off the specie standard. Thèse de Ph.D., University of Western Ontario, 1982.

220. RUSSELL, Peter A. «Upper Canada: a poor man's country? Some statistical evidence», Donald H. Akenson, Canadian papers in rural history - Volume III (Gananoque, Langdale Press, 1982): 129-147.

221. SCOLLARD, Robert J. A calendar of the deceased bishops, priests and deacons of the Archdiocese of Toronto. $3^{\mathrm{e}}$ ed. Toronto, University of St. Michael's College, 1981. $52 \mathrm{p}$.

222. SCOLLARD, Robert J. Footprints in the sand of Cloverhill: anniversaries, and notable events in the history of St. Michael's College, 1852-1977. Toronto, University of St. Michael's College Archives, 1977, 55 p.

223. SHELTON, W.G. «The united empire loyalists: a reconsideration», R. Douglas Francis et Donald B. Smith, Readings in Canadian history - Pre-confederation (Toronto, Holt, Rinehart and Winston, 1982): 272-281.

224. SPELT, Jacob. «The building of the railways», R. Douglas Francis et Donald B. Smith, Readings in Canadian history - Pre-confederation (Toronto, Holt, Rinehart and Winston, 1982): 371-388.

225. VILLENEUVE, Mark Randall. A history of policing in Gloucester, 1850 to 1982 . Gloucester (Ont.), [Board of Commissionners of Police for the City of Gloucester], 1982, ix, $66 \mathrm{p}$.

226. WIDDIS, Randy William. «Speculation and the Surveyor: An Analysis of the Role Played by the Surveyors in the Settlement of Upper Canada», Histoire sociale / Social history, 15, 30 (nov. 1982): 443-458. 
227. WISE, Sydney F. «Upper Canada and the conservative tradition», R. Douglas Francis et Donald B. Smith, Readings in Canadian history - Pre-confederation (Toronto, Holt, Rinehart and Winston, 1982): 281-294.

\section{VOIR AUSSI: 84.}

\section{5 - L'OUEST ET LE NORD}

228. AKRIGG, G.P.V. «The Fraser river gold rush», The Fraser's history from glaciers to early settlements (Burnaby (C.-B.), Burnaby historical society, [1981?]): 29-38.

229. CAMPBELL, Marjorie Wilkins. The North West Company. Vancouver, Douglas \& McIntyre, 1983. $295 \mathrm{p}$.

230. CARELESS, J.M.S. «The Lowe Brothers, 1852-70: a study in business relations on the North Pacific coast», R. Douglas Francis et Donald B. Smith, Readings in Canadian history - Pre-confederation (Toronto, Holt, Rinehart and Winston, 1982): 438-453.

231. CARELESS, J.M.S. «The Lowe Brothers, 1852-70: a study in business relations on the north pacific coast», W. Peter Ward et Robert A.J. McDonald, British Columbia: Historical readings (Vancouver, Douglas \& McIntyre, 1981): 277-295.

232. CARAFFE, Marc de. L'enseignement en pays de mission: les écoles des Territoires du Nord-Ouest et du Yukon avant 1930. Coll. «Bulletin de recherches» no 187. [Ottawa], Parcs Canada, 1983. $10 \mathrm{p}$.

233. DONALDSON, Bruce. York Factory, 1821-1870. Coll. «Bulletin de recherches» no 173. [Ottawa], Parcs Canada, 1982. 36p.

234. GIBSON, James R. «Bostonians and Muscovites on the northwest coast, 1788-1841»W. Peter Ward et Robert A.J. McDonald, British Columbia: Historical readings (Vancouver, Douglas \& McIntyre, 1981): 66-95.

235. GOUGH, Barry M. «The character of the British Columbia frontier», W. Peter Ward et Robert A.J. McDonald, British Columbia: Historical readings (Vancouver, Douglas \& McIntyre, 1981): 232-244.

236. HENDRICKSON, James E. «The constitutional development of colonial Vancouver Island and British Columbia», W. Peter Ward et Robert A.J. McDonald, British Columbia: Historical readings (Vancouver, Douglas \& McIntyre, 1981): 245-274.

237. KARAMANSKI, Theodore John. Fur trade and exploration: opening the Far Nortwest, 1821-1852. Vancouver, University of British Columbia Press, 1983. xxii, $330 \mathrm{p}$.

238. McCARTHY, Martha. The missions of the Oblates of Mary Immaculate to the Athapaskans 1846-1870: theory, structure and method. Thèse de Ph.D., Université du Manitoba, 1981.

239. «Northern Frontier, Northern homeland», R. Douglas et Donald B. Smith, Readings in Canadian History - Post-Confederation (Toronto, Holt, Rinehart and Winston, 1982): 560-593. (Extrait du rapport de la commission Berger).

240. RICHESON, David. «The north, the western interior, and the Pacific coast», D.A. Muise, A reader's guide to Canadian History -2 Beginnings to Confederation (Toronto, University of Toronto Press, 1982): 161-192.

241. ZILM, Glennis. Early B.C. books: an overview of trade book publishing in British Columbia in the 1800s with checklists and selected bibliography related to British Columbians. Thèse de M.A. Université Simon Fraser, 1981.

242. WALLACE, Hugh N. «Geographic explorations to 1880», Morris Zaslow, Un siècle des iles arctiques du Canada / 1880-1980 / A century of Canada's arctic islands (S.L., La société royale du Canada, 1981): 15-32.

VOIR AUSSI: 3; 8; 10; 11; 12; 29; 40; 81; 141. 


\section{IV - LA CONFÉDÉRATION \\ 1 - HISTOIRE GÉNÉRALE}

243. A Statistical portrait of Canadian higher education from the 1960's to the 1980's. Ottawa, Statistics Canada, Education, Science and Culture Division, 1983. 73 p.

244. ABELLA, Irving et Harold TROPER. «The politics of futility: Canadian jews and the refugee crisis, 1933-1939», Jorgen Dahlie et Tissa Fernando, Ethnicity, Power and politics in Canada (Toronto, Methuen, 1981): 233-253.

245. ALLEN, Alexander Richard. «The social gospel and the reform tradition in Canada, 18901928», R. Douglas et Donald B. Smith, Readings in Canadian history - Post-confederation (Toronto, Holt, Rinehart and Winston, 1982): 271-287.

246. «An open letter from Capt. Talbot Papineau to Mr. Henri Bourassa», «Mr. Bourassa's reply to Capt. Talbot Papineau's letter», R. Douglas et Donald B. Smith, Readings in Canadian history - Post-confederation (Toronto, Holt, Rinehart and Winston, 1982): 345-360.(Participation ou non-participation du Canada à la guerre de 1914-18).

247. ANDREWS, Paul Martin. Limits of coexistence: the U.S.S. Nashville and the presence of armed American Naval training vessels on the Great Lakes. Thèse de M.A., Université McGill, 1981.

248. AUDETTE, L.C. «The lower deck and the Mainguy report of 1949», James A. Boutilier, The RCN in retrospect 1910-1968 (Vancouver, University of British Columbia Press, 1982): 235-249.

249. AVERY, Donald Howard. «Ethnic loyalties and the proletarian revolution: a case study of communist political activity in Winnipeg, 1923-1936», Jorgen Dalhie et Tissa Fernando, Ethnicity, Power and politics in Canada (Toronto, Methuen, 1981): 68-93.

250. AVERY, Donald Howard et J.K. FEDOROWICZ. Les polonais au Canada. Coll. «Les groupes ethniques du Canada» no 4. Ottawa, Société historique du Canada, 1982. $24 \mathrm{p}$.

251. BARBOUR, Douglas et Marni L. STANLEY. Writing right: poetry by Canadian women. Edmonton, Longspoon Press, 1982. 192 p.

252. BARER, Morris Lionel. Prices, proxies and productivity: an historical analysis of hospital and medical care in Canada. Vancouver, Dept. of Economics, the University of British Columbia, $1983.56 \mathrm{p}$.

253. BEESLEY, Patrick. «Operational intelligence and the battle of the Atlantic: the role of the royal navy's submarine tracking room», James $\mathrm{A}$. Boutilier, The RCN in retrospect 1910-1968 (Vancouver, University of British Columbia Press, 1982): 175-186.

254. BERGER, Carl. «Imperialism or nationalism: 1884-1914», R. Douglas Francis et Donald B. Smith, Readings in Canadian history - Post-confederation (Toronto, Holt, Rinehart and Winston, 1982): 94-99.

255. BERGERON, Chantal et al. Répertoire bibliographique de textes de présentation générale et d'analyse d'oeuvres musicales canadiennes (1900-1980) / Canadian musical [...] sources. Ottawa, Association canadienne des bibliothèques musicales, 1983. xiv, $96 \mathrm{p}$.

256. BERNIER, J.E. Les mémoires de J.E. Bernier. Montréal, Quinze, 1983. 205 p.

257. BIRRELL, Andrew et al. «Private Realms of Light: Canadian Amateur Photography, 18391940», Archivaria, 17 (hiv. 1983-1984): 106-144.

258. BISZTRAY, George. "Why 1956? Recent cultural changes in the Hungarian canadian community», Martin L. Kovacs, Roots and realities among eastern and central europeans (Edmonton, Central and East European Studies Association of Canada, 1983): 165-173.

259. BOURASSA, Henri. «The French-Canadian in the British empire», R. Douglas et Donald B. Smith, Readings in Canadian history - Post-confederation (Toronto, Holt, Rinehart and Winston, 1982): 113-121.

260. BOVEY,John. «The destroyers war in Korea, 1952-53», James A. Boutilier, The RCN in retrospect 1910-1968 (Vancouver, University of British Columbia Press, 1982): 250270. 
261. BRAY, R. Matthew' «Fighting as an ally: the English Canadian patriotic response to the great war», R. Douglas et Donald B. Smith, Readings in Canadian history - Postconfederation (Toronto, Holt, Rinehart and Winston, 1982): 322-344.

262. BRIAN, John. David Milne and the modern tradition of painting. Toronto, Coach House Press, 1983. $141 \mathrm{p}$.

263. BROCK, P. Willet. «Commander E.A.E. Nixon and the royal naval college of Canada, 1910-1922», James A. Boutilier, The RCN in retrospect 1910-1968 (Vancouver, University of British Columbia Press, 1982): 33-43.

264. BRODEUR, Nigel D. «L.P. Brodeur and the origins of the royal canadian navy», James A. Boutilier, The RCN in retrospect 1910-1968 (Vancouver, University of British Columbia Press, 1982): 13-32.

265. BRODIE, M. Janine. Pathways to public office: Canadian women in the post-war years. Thèse de Ph. D., Université de Carleton, 1981.

266. BRODIE, M. Janine et Jane JENSON. «The party system», Michael S. Whittington et Glen Williams, Canadian politics in the 1980s (Toronto, Methuen, 1981): 189-205.

267. BROWN, Robert Craig. «The nationalism of the national policy», R. Douglas Francis et Donald B. Smith, Readings in Canadian history - Post-confederation (Toronto, Holt, Rinehart and Winston, 1982): 22-28.

268. BUCHIGNANI, Norman et Doreen INDRA. «The political organization of south Asians in Canada, 1904-1920», Jorgen Dahlie et Tissa Fernando, Ethnicity, Power and politics in Canada (Toronto, Methuen, 1981): 202-232.

269. BUTLER, Dan et Bruce D. MACNAUGHTON. «Public sector growth in Canada: Issues, explanations and implications», Michael S. Whittington et Glen Williams, Canadian politics in the 1980s (Toronto, Methuen, 1981): 84-107.

270. CALDER, W.A. «Convict life in canadian federal penitentiaries, 1867-1900», Louis A. Knafla, Crime and Criminal justice in Europe and Canada (Waterloo, Wilfrid Laurier University Press, 1981): 297-318.

271. CAMERON, A. Keith. «The royal canadian navy and the unification crisis», James A. Boutilier, The RCN in retrospect 1910-1968 (Vancouver, University of British Columbia Press, 1982): 334-342.

272. CHRISTIAN, William et Colin CAMPBELL. Political parties and ideologies in Canada: liberals, conservatives, socialists, nationalists. Toronto, McGraw-Hill Ryerson, 1983. $\mathrm{xv}, 247 \mathrm{p}$.

273. CORBETT, Brian et Eldon FROST. «The Acquisition of Federal Government Records: A Report on Records Management and Practices», Archivaria, 17 (hiv. 1983-1984): 201232.

274. COURCHESNE, Thomas-J. «The interaction between economic theory and bank of Canada policy», David C. Smith, Economic policy advising in Canada - Essays in honour of John Deutsch Montreal, C.D. Howe Institute, 1981): 147-189.

275. CRANSTONE, Donald Alfred. An analysis of ore discovery cost and rates of ore discovery in Canada over the period 1946 to 1977. Thèse de Ph. D., Harvard University, 1982.

276. DALES, John H. «Some historical and theoretical comment on Canada's national policies», R. Douglas Francis et Donald B. Smith, Readings in Canadian history - Postconfederation (Toronto, Holt, Rinehart and Winston, 1982): 29-43.

277. DANCOCKS, Daniel G. In enemy hands: Canadian prisoners of war, 1939-45. Edmonton, Hurtig, 1983. xvi, $303 \mathrm{p}$.

278. DODD, Dianne. «The Canadian Birth Control Movement on Trial, 1936-1937», Histoire sociale/ Social history, 16, 32 (nov. 1983): 411-428.

279. DOLZANI, Michael. «The infernal method: Northrop Frye and contemporary criticism», Eleanor Cook, Centre and labyrinth - Essays in honour of Northrop Frye (Toronto, University of Toronto Press, 1983): 59-68.

280. DOUGLAS, W.A.B. et Jurgen ROHWER. «The most thankless task revisited: convoys, escorts, and radio intelligence in the western Atlantic, 1941-43», James A. Boutilier, The RCN in retrospect 1910-1968 (Vancouver, University of British Columbia Press, 1982): $187-234$. 
281. DRAPER, James A. Adult education theses, Canada. Toronto, Department of Adult Education, Ontario Institute for Studies in Education, 1981. iv, 165 p.

282. DRYSTEK, Henry F. «The Simplest and Cheapest Mode of Dealing with Them»: Deportation from Canada before World War II», Histoire sociale/ Social history, 15, 30 (nov. 1982): 407-441.

283. EVANS, Paul A. The Canadian federal budget of 1957. Thèse de M.A., Université de Waterloo, 1981.

284. FOWLER, Robert M. «The role of Royal commissions», David C. Smith, Economic policy advising in Canada - Essays in honour of John Deutsch (Montreal, C.D. Howe Institute, 1981): 93-104.

285. FRANCIS, R. Douglas et Donald Boyd SMITH. Readings in Canadian history - Postconfederation. Toronto, Holt, Rinehart and Winston of Canada, 1982. 622 p.

286. FRANK, Murray. Expected inflation in Canada, 1965-1979; how rational are business forecasts? Kingston (Ont.), Institute for Economic Research, Queen's University, 1982. $9,[9] \mathrm{p}$.

287. FRENCH, William E. The nature of Canadian investment in Mexico, 1902-1915 a study of the incorporation and history of the Mexican Light and Power Company, the Mexico Tramways Company and the Mexico North Western Railway. Thèse de M.A. Université de Calgary, 1981.

288. GLICKMAN, Yaacov. «Political socialization and the social protest of Canadian Jews: some historical and contemporary perspectives», Jorgen Dahlie et Tissa Fernando, Ethnicity, Power and politics in Canada (Toronto, Methuen, 1981): 123-150.

289. GLICKMAN, Yaacov. The treatment of the Holocaust in Canadian history and social science textbooks. Downsview (Ont.), Leaggue for Human Rights of B'nai Brith Canada, 1982. xiv, $101 \mathrm{p}$.

290. GOODMAN, Jeffrey. Hudding up: the inside story of Canada Football League. Don Mills (Ont.), Fitzhenry \& Whiteside, 1982. 256 p.

291. GUNTON, Thomas I. The evolution of urban and regional planning of Canada, 19001960. Thèse de $\mathrm{Ph} . \mathrm{D}$., Université de Colombie-Britannique, 1981.

292. HADLEY, Michael. «The impact of public policy on a naval reserve division», James A. Boutillier, The RCN in retrospect 1910-1968 (Vancouver, University of British Columbia Press, 1982): 308-316.

293. HELLIWELL, John F. Stagflation and productivity decline in Canada, 1974-1982. Kingston (Ont.), Institute for Economic Research, Queen's University, [1983]. 27, [8] p.

294. HOLMES, John W. «Canadian external policies since 1945», R. Douglas et Donald B. Smith, Readings in Canadian history - Post-confederation (Toronto, Holt, Rinehart and Winston, 1982): 493-501.

295. HUMBER, William. Cheering for the home team: the story of baseball in Canada. Erin (Ont.), Boston Mills Press, 1983. 150 p.

296. HUNT, Barry D. «The road to Washington: Canada and empire naval defence 1918-1921,» James A. Boutilier, The RCN in retrospect 1910-1968 (Vancouver, University of British Columbia Press, 1982): 44-61.

297. IRVING, John A. «The evolution of the social credit movement», R. Douglas et Donald B. Smith, Readings in Canadian history - Post-confederation (Toronto, Holt, Rinehart and Winston, 1982): 390-412.

298. KALMAN, Bobbie. Early village life. Toronto, Crabtree Pub., 1981. 64 p.

299. KEEFER, T.C. «Philosophy of railroads», R. Douglas Francis et Donald B. Smith, Readings in Canadian history - Pre-confederation (Toronto, Holt, Rinehart and Winston, 1982): 362-371.

300. KERNAGHAN, Kenneth et T.H. McLEOD. «Mandarins and ministers in the Canadian administrative state», O.P. Dwivedi, The administrative state in Canada - Essays in honour of J.E. Hodgetts (Toronto, University of Toronto Press, 1982): 17-30.

301. KEYSERLINGK, Robert H. «Policy or practice: Canada and Austria 1938-1948», Martin L. Kovacs, Roots and realities among eastern and central Europeans (Edmonton, Central and East European Studies Association of Canada, 1983): 25-39. 
302. KNOX, J.H.W. «An engineer's outline of RCN history», James A. Boutilier, The RCN in retrospect 1910-1968 (Vancouver, University of British Columbia Press, 1982): 96$115 ; 317-333$.

303. KOVACS, Martin L. «Settlement, depression and alienation: an episode from early prairie history», Martin L. Kovacs, Roots and realities among eastern and central Europeans (Edmonton, Central and East European Studies Association of Canada, 1983): 137153. (Hongrois).

304. KURTZ, Morris. A history of the 1972 Canada-USSR ice hockey series. Thèse de Ph.D., Pennsylvania State University. 1981.

305. L'ESPÉRANCE, Jeanne. Vers des horizons nouveaux: la femme canadienne de 1870 à 1940 / The widening sphere [...]. Ottawa, Archives publiques Canada, 1982. 69 p.

306. LAINE, Edward W. «Finnish Canadian radicalism and Canadian politics: the first forty years, 1900-1940», Jorgen Dahlie et Tissa Fernando, Ethnicity, Power and politics in Canada (Toronto, Methuen, 1981): 94-112.

307. LEACOCK, Stephen. "Greater Canada: an appeal - Let us no longer be a colony», R. Douglas Francis et Donald B. Smith, Readings in Canadian history - Post-confederation (Toronto, Holt, Rinehart and Winston, 1982): 108-113.

308. LEDERMAN, William Ralph. Continuing Canadian constitutional dilemmas: essays on the constitutional history, public law and federal system of Canada. Toronto, Butterworths, 1981. xiii, 442 p.

309. LEIR, Richard H. «Big ship time»: the formative years of RCN officers serving in RN capital ships», James A. Boutilier, The RCN in retrospect 1910-1968 (Vancouver, University of British Columbia Press, 1982): 74-95.

310. LÉVESQUE, Terrence J. et James W. MOORE. «Citizen and Provincial Power Under Alternative Amending Formulae: An Extension of Kilgour's Analysis», Revue canadienne de science politique / Canadian Journal of Political Science, 17, 1 (mars 1984): 157-166.

311. LEVITT, Joseph. A Vision Beyond Reach: A Century of Images of Canadian Destiny. Ottawa, Deneau, 1982. iv, 237 p.

312. LEVITT, Karl. «Metropolis and hinterland», R. Douglas et Donald B. Smith, Readings in Canadian history - Post-confederation (Toronto, Holt, Rinehart and Winston, 1982): 511-526. (Investissements).

313. LEVITT, Karl. «Regression to dependance», R. Douglas et Donald B. Smith, Readings in Canadian history - Post-confederation (Toronto, Holt, Rinehart and Winston, 1982): 503-511. (Corporations multinationales).

314. LEWIS, Leopold Alban. The shaping of anti-inflation policy in Canada, 1968-1980: the theory and politics of inflation. Thèse de M.A., Université Carleton, 1982.

315. LINDSTROM-BEST, Varpu. «Fist press»: a study of the Finnish-Canadian handwritten newspapers», Martin L. Kovacs, Roots and realities among eastern and central europeans (Edmonton, Central and East European Studies Association of Canada, 1983): 129-136.

316. LINDSTROM-BEST, Varpu. «The socialist party of Canada and the Finnish connection, 1905-1911», Jorgen Dahlie et Tissa Fernando, Ethnicity, Power and politics in Canada (Toronto, Methuen, 1981): 113-122.

317. LUND, W.G.D. «The royal canadian navy's quest for autonomy in the north west Atlantic», James A. Boutilier, The RCN in retrospect 1910-1968 (Vancouver, University of British Columbia Press, 1982): 138-157.

318. McCALL-NEWMAN, Christina. Grits: An Intimate Portrait of the Liberal Party. Toronto, McMillan of Canada, 1982. x, 481 p.

319. McCORMACK, Ross. «Cloth caps and jobs: the ethnicity of English immigrants in Canada 1900-1914», Jorgen Dahlie et Tissa Fernando, Ethnicity, Power and politics in Canada (Toronto, Methuen, 1981): 38-55.

320. McKEE, Fraser M. «Princes three: Canada's use of armed merchant cruisers during world war II», James A. Boutilier, The RCN in retrospect 1910-1968 (Vancouver, University of British Columbia Press, 1982): 116-137. 
321. MANDEL, Eli. «Northrop Frye and the Canadian literary tradition», Eleanor Cook, Centre and labyrinth - Essays in honour of Northrop Frye (Toronto, University of Toronto Press, 1983): 284-297.

322. MARSHALL, Noreen K. From Pearson to Brandt: implications for Canadian foreign aid policy and practice. Thèse de M.A. Dalhousie University, 1982.

323. MARTINEZ, Michael D. «Intergenerational Transfer of Canadian Partisanships», Revue canadienne de science politique / Canadian Journal of Political Science, 17, 1 (mars 1984): 133-143.

324. MELADY, John. Korea: Canada's forgotten war. Toronto, Macmillan of Canada, 1983. viii, 215 p.

325. MERCER, Robert A.N. Trails: a 50-year history of the Canadian Cattlemen's Association and the industry surrounding it: 1932-1982. Markham (Ont.), Broadwater Farm Services. 1982. vii, $77 \mathrm{p}$.

326. MILNER, Marc. «Royal canadian navy participation in the battle of the atlantic crisis of 1943», James A. Boutilier, The RCN in Retrospect 1910-1968 (Vancouver, University of British Columbia Press, 1982): 158-174.

327. MOUNT, Graeme Stewart. Presbyterian missions to Trinidad and Puerto Rico. Hantsport (N.-É.), Lancelot Press, 1983. 356 p.

328. «National development in the arts, letters ans sciences», R. Douglas et Donald B. Smith, Readings in Canadian history - Post-confederation (Toronto, Holt, Rinehart and Winston, 1982): 526-548. (Extrait du rapport de la commission Massey).

329. O'DRISCOLL, Herbert. One man's journal. Toronto, Anglican Book Centre, 1982. 160 p.

330. PAYNE, Julien D. Payne's digest on divorce in Canada, 1968-1980. Don Mills (Ont.), R. De Boo, [1982]. xxiv, 1043 p.

331. PEDERSEN, Diana Lynn. Keeping our good girls good: the Young Women's Christian Association of Canada, 1870-1920. Thèse de M.A., Université Carleton, 1981.

332. PRICE, William Joseph. Go forth with God!: The history of the Bay of Quinte Conference of the United church of Canada, 1925-1975. Thèse de Ph. D., University of Ottawa, 1981.

333. PROSS, A. Paul. «Space, function, and interest: the problem of legitimacy in the Canadian State», O.P. Dwivedi, The administrative state in Canada-Essays in honour of J.E. Hodgetts (Toronto, University of Toronto Press, 1982): 107-129.

334. PULLEN, Hugh Francis. «The royal canadian navy between the wars», James A. Boutilier, The RCN in retrospect 1910-1968 (Vancouver, University of British Columbia Press, 1982): 62-73.

335. QUINN, Magella. Le magasin général, 1910-1930. Coll. «Bulletin de recherches» no 186. [Ottawa], Parcs Canada, 1983. 19 p.

336. RICOEUR, Paul. «Anatomy of criticism», or the order of paradigms», Eleanor Cook, Centre and labyrinth - Essays in honour of Northrop Frye (Toronto, University of Toronto Press, 1983): 1-13.

337. RITCHIE, Charles. Storm signals: more undiplomatic diaries, 1962-1971. Toronto, Macmillan of Canada, 1983. x, $175 \mathrm{p}$.

338. RUTHERFORD, Paul. «Tomorrow's metropolis: the urban reform movement in Canada, 1880-1920», R. Douglas Francis et Donald B. Smith, Readings in Canadian history - Post-confederation (Toronto, Holt, Rinehart and Winston, 1982): 303-320.

339. SAUTTER, Udo. «Measuring Unemployment in Canada: Federal Efforts before World War II», Histoire sociale / Social history, 15, 30 (nov. 1982): 475-487.

340. SMITH, Goldwin. «Canada and the canadian question», R. Douglas Francis et Donald B Smith, Readings in Canadian history - Post-Confederation (Toronto, Holt, Rinehart and Winston, 1982): 99-108.

341. SOWARD, Stuart. «Canadian naval aviation 1915-69», James A. Boutilier, The RCN in retrospect 1910-1968 (Vancouver, University of British Columbia Press, 1982): 271285.

342. STACEY, C.P. «The canadian effort, 1939-45: a general survey», R. Douglas et Donald B. Smith, Readings in Canadian history - Post-confederation (Toronto, Holt, Rinehart and Winston, 1982): 448-493. 
343. STIDWILL, Howard F. The history of the Canadian Olympic Association. Thèse de M.P.E., Université d'Ottawa, 1981.

344. STRUTHERS, James. No fault of their own: unemployment and the Canadian welfare state, 1914-1941. Toronto, University of Toronto Press, 1983. x, 268 p.

345. SUNAHARA, Ann Gomer. «Deportation: the final solution to Canada's Japanese problem», Jorgen Dahlie et Tissa Fernando, Ethnicity, Power and politics in Canada (Toronto, Methuen, 1981): 254-278.

346. TAYLOR, Charles. Radical Tories: The Conservative Tradition in Canada. Toronto, House of Anansi, 1982. 231 p.

347. TONER, Glen et François BREGHA. «The political economy of energy», Michael S. Whittington et Glen Williams, Canadian politics in the 1980s (Toronto, Methuen, 1981): 1-26.

348. TURNER, Robert D. The Pacific Empresses: an illustrated history of the Canadian Pacific Railway's Empress liners on the Pacific Ocean. Victoria, Sono Nis Press, 1981. x, 290 p.

349. VELDHEER, Peter A. Daar komen de Canadezen: de zegevierende opmars van het Eerste Canadese Legerkorps over de Veluwe naar West-Nederland in 1945. Arnhem, Gijsbers \& Van Loon. 1982, 227 p. (Guerre 1939-45).

350. WARD, W. Peter. «British Columbia and the Japanese Evacuation», W. Peter Ward et Robert A.J. McDonald, British Columbia: Historical readings (Vancouver, Douglas, McIntyre, 1981): 671-692.

351. WARREN, C. Leigh et Paul C. RUMP. The urbanization of rural land in Canada, 19661971 and 1971-1976 / Urbanisation des terres rurales au Canada, 1966-1971 et 19711976. Ottawa, Programme de surveillance de l'utilisation des terres, Environnement Canada, 1981. xi, 283 p.

352. WATSON, A. John. Marginal man: Harold Innis' communications work in context. Thèse de Ph.D., Université de Toronto, 1981.

353. WICKBERG, Edgar. «Chinese organizations and the canadian political process: two case studies», Jorgen Dahlie et Tissa Fernando, Ethnicity, Power and politics in Canada (Toronto, Methuen, 1981): 172-176.

354. WRIGHT, Glenn T. «Canadian Pacific at the Glenbow: A Hundred Years of the CPR in Western Canada», Archivaria, 17 (hiv. 1983-1984): 278-285.

355. YOUNG, Walter D. «The radical background of the CCF», R. Douglas et Donald B. Smith, Readings in Canadian history - Post-confederation (Toronto, Holt, Rinehart and Winston, 1982): 413-432.

356. ZITKO, Carley F. The structure of cabinet government in Canada, 1968-72: an assessment. Thèse de M.A., Université de Colombie-Britannique, 1981.

VOIR AUSSI: 42; 47; $86 ; 88 ; 90 ; 91 ; 92 ; 93 ; 94 ; 95 ; 97 ; 101 ; 102 ; 103 ; 105 ; 108 ; 109 ; 110 ;$ $111 ; 112 ; 113$.

\section{2 - LES PROVINCES DE L'ATLANTIQUE}

357. ALEXANDER, David G. Atlantic Canada and Confederation-Essays in political economy. Toronto, University of Toronto press, 1983. xviii, $157 \mathrm{p}$.

358. ARSENAULT, Georges. «The Acadian Experience in Prince Edward Island», La Société historique acadienne - Les cahiers, 14, 2 (juin 1983): 59-72.

359. BURANT, Jim. «A Written Portrait: Saint John Photographers and Their Studios in the 1871 Census», Archivaria, 17 (hiv. 1983-1984): 275-277.

360. BURNETT, David. Colville. Toronto, Art Gallery of Ontario, 1983. 272 p.

361. CAIRNS, John S. Louis Davies and Prince Edward Island politics. 1869-1879. Thèse de M.A., Université Dalhousie, 1982.

362. CARELESS, J.M.S. «Aspects of metropolitanism in Atlantic Canada», R. Douglas et Donald B. Srnith, Readings in Canadian history - Post-confederation (Toronto, Holt, Rinehart and Winston, 1982): 206-217. 
363. DAVIES, Margot. Calling Newfoundland: poems, 1940-41. Norfolk, Warren House Press, 1982. xxiii, $56 \mathrm{p}$.

364. EVANS, Allen. The splendour of St. Jacques. St.-Jean (T.-N.), Nfld, H. Cuff Publications, 1981. 67 p. (autobiographie).

365. FISHER, Lewis R., Eric W. SAGER et Rosemary E. OMMER. «The shipping industry and regional economic development in Atlantic Canada, 1871-1891: Saint John as a case study», Lewis R. Fisher et Eric W. Sager, Merchant shipping and economic development in Atlantic Canada (Saint-Jean, Université Memorial, 1981): 35-53.

366. FORBES, Ernest Robert. Aspects of Maritime regionalism, 1867-1927. Coll. «Historical booklet» no 36. Ottawa, Canadian Historical Association, 1983. 25 p.

367. FORBES, Ernest Robert. «The origins of the maritime rights movement», R. Douglas et Donald B. Smith, Readings in Canadian history - Post-confederation (Toronto, Holt, Rinehart and Winston, 1982): 376-388.

368. GAUTREAU, G.-A. «Les chantiers ( $2^{\mathrm{e}}$ partie)», La revue d'histoire de la Société historique Nicolas-Denys, 10, 1 (janv.-mars 1982): 25-52.

369. GEORGE, Roy E. «Fifteen years of regional industrial development policy: a case study of Nova Scotia», Lewis R. Fischer et Eric W. Sager, Merchant shipping and economic development in Atlantic Canada (Saint-Jean, Université Memorial, 1981): 167-183.

370. GOSS, R.O. «Economics and Canadian Atlantic shipping», Lewis R. Fischer et Eric W. Sager, Merchant shipping and economic development in Atlantic Canada (Saint-Jean, Université Memorial, 1981): 89-112.

371. HAMMOND, John W. Wabana: a history of Bell Island from 1893-1940. Grand Manan (N.-B.), [J.W. Hammond], 1982. 76 p.

372. HARLEY, C. Knick. «Issues on the demand for shipping services, 1870-1913: derived demand and problems of joint production», Lewis R. Fischer et Eric W. Sager, Merchant shipping and economic development in Atlantic Canada (Saint-Jean, Université Memorial, 1981): 67-85.

373. JONES, Ted. All the days of his life: a biography of Archdeacon H.A. Cody. Saint-Jean, New-Brunswick Museum, 1981. 428 p.

374. LANDRY, Jean-Pierre. «Aperçu de l'histoire de la radio et de la télévision française des Maritimes (de 1933 à 1960)», La Société historique acadienne - Les cahiers, 14, 3 (sept. 1983): 75-90.

375. MACLEOD, Donald. «Our Man in the Maritimes: «Down East> with the Public Archives of Canada, 1872-1932», Archivaria, 17 (hiv. 1983-1984): 86-105.

376. MOWAT, Farley. Grey seas under. Toronto, McClelland and Stewart-Bantam, 1981. $255 \mathrm{p}$.

377. PATEY, Effie. Major Eva of Calcuta. [Toronto], Salvation Army, [1981]. 80 p. (Eva Crann).

378. ROBICHAUD, Donat. "À la conquête de l'or», La revue d' histoire de la Société historique Nicolas-Denys, 10, 1 (janv.-mars 1982): 3-24. (Les départs vers le Klondyke)

379. ROBICHAUD, Donat. «Les tremblements de terre dans le Nord-Est», La revue d' histoire de la Société historique Nicolas-Denys, 10, 1 (janv.-mars 1982): 53-56. (Au NouveauBrunswick).

380. SHEDDEN, Leslie. Mining photographs and other pictures, 1948-1968: a selection from the Negative Archives of Shedden Studio, Glace Bay, Cape Breton. Halifax, Press of the Nova Scotia of Art and Design and the University College of Cape Breton Press, 1983. xxviii, $277 \mathrm{p}$.

381. THORNE, Richard Gregory. Aspects of the political career of J.V. Ellis 1867-1891. Thèse de M.A., Université du Nouveau-Brunswick, 1981.

382. THORNTON, Patricia. «Some preliminary comments on the extent and consequences of out-migration from the Atlantic region, 1870-1920», Lewis R. Fischer et Eric W. Sager, Merchant shipping and economic development in Atlantic Canada (Saint-Jean, Université Memorial, 1981): 187-218.

383. WARNER, Donald F. «The post-confederation annexation movement in Nova Scotia», $\mathbf{R}$. Douglas Francis et Donald B. Smith, Readings in Canadian history - Post-Confederation (Toronto, Holt, Rinehart and Winston, 1982): 2-10. 
384. YOUNG, Alan R. Thomas Head Raddal: a bibliography. Kingston (Ontario), Loyal Colonies Press, 1982. xi, 72 p.

VOIR AUSSI: 119; 121; 122; 126; 128; 129; 130; 132; 134; 139; 140; 141.

\section{3 - LE QUÉBEC}

385. ALLAIRE, Micheline D'. «Le coutumier des religieuses - Codificateur de vie?», Benoit Lacroix et Jean Simard, Religion populaire - Religion de clercs? (Québec, Institut québécois de recherche sur la culture, 1984): 235-255.

386. ANGELL, Harold M. «Le financement des partis politiques provinciaux du Québec», Vincent Lemieux, Personnel et partis politiques au Québec - Aspects historiques (Montréal, Boréal Express, 1982): 69-89.

387. AONZO, Jeannine. La femme dans les romans d'Anne Hébert. Thèse de M.A., Université McGill, 1981.

388. ARCHIBALD, Clinton. Corporatisme et néocorporatisme au Québec, une constante négligée: 1930 à nos jours. Thèse de Ph.D., Université Carleton, 1982.

389. ARMSTRONG, Christopher et H. V. NELLES. «Contrasting Development of the HydroElectric Industry in the Montreal and Toronto Regions, 1900-1930», Journal of Canadian Studies/ Revue d'études canadiennes, 18, 1 (print. 1983): 5-27.

390. BEAUD, Jean-Pierre. «Hiérarchie et sélection sociale: l'exemple du Parti québécois (19681978)», Vincent Lemieux, Personnel et partis politiques au Québec - Aspects historiques (Montréal, Boréal Express, 1982): 229-252.

391. BEAULIEU, J.-François. «Trois-Pistoles. Nom légendaire ou historique», L'Écho des Basques, 4, 1 (déc. 1983): 57.

392. BÉLANGER, André-J. «Guy Frégault au temps de «La relève» », Pierre Savard, Guy Frégault (1918-1977) (Montréal, Bellarmin, 1981): 17-25.

393. BELLAVANCE, Michel. «L'analyse des discours du budget: le cas du Québec, 19601980», Journal of Canadian Studies/ Revue d'études canadiennes, 18, 1 (print. 1983): 92-116.

394. BLAIS, André et Kenneth McROBERTS. «Public Expenditure in Ontario and Quebec, 1950-1980: Explaining the Differences», Journal of Canadian Studies/ Revue d'études canadiennes, 18, 1 (print. 1983): 28-53.

395. BOILY, Robert. «Les hommes politiques du Québec, 1867-1967», Vincent Lemieux, Personnel et partis politiques au Québec - Aspects historiques (Montréal, Boréal Express, 1982): 93-117.

396. BOLDUC, Roch et James Iain GOW. «Environment and administration: Quebec, 18671980», O.P. Dwivedi, The administrative state in Canada - Essays in honour of J.E. Hodgetts (Toronto, University of Toronto Press, 1982): 31-61.

397. BOUCHARD, René. «Documents filmiques sur la religion traditionnelle des Québécois», Benoit Lacroix et Jean Simard, Religion populaire - Religion de clercs? (Québec, Institut québécois de recherche sur la culture, 1984): 193-213.

398. BOULANGER, André. Marcel Martel: au jardin de mes souvenirs. Boucherville (Québec), Éditions de Mortagne, 1983. 383 p.

399. BOURASSA, Guy. «Les élites politiques de Montréal: de l'aristocratie à la démocratie», Vincent Lemieux, Personnel et partis politiques au Québec - Aspects historiques (Montréal, Boréal Express, 1982): 255-276.

400. BOURBEAU, Robert. Les accidents de la route au Québec. 1926-1978: étude démographique et épidémiologique. Montréal, Presses de l'Université de Montréal, 1983. 424 p.

401. BRUNET, Michel. «Guy Frégault: l'itinéraire d'un historien de «La civilisation de la Nouvelle-France» (1944) à «La Guerre de la Conquête» (1955)», Pierre Savard, Guy Frégault (1918-1977) (Montréal, Bellarmin, 1981): 27-39.

402. CARAFFE, Marc de. Le sort des écoles publiques entre 1876 et 1930. Coll. «Bulletin de recherches» no 189. [Ottawa], Parcs Canada, 1983. 22 p. 
403. CHALOULT, Michel. «La structure des partis politiques dans l'Est du Québec», Vincent Lemieux, Personnel et partis politiques au Québec - Aspects historiques (Montréal, Boréal Express, 1982): 155-174.

404. COLLIN, Jean-Pierre. «Le partage fiscal banlieue-ville centrale: les Montréalais subventionnent-ils les banlieusards?», Revue canadienne de science-politique / Canadian Journal of Political Science, 17, 1 (mars 1984): 109-131.

405. COMEAU, Paul-André. «La transformation du parti libéral québécois», Vincent Lemieux, Personnel et partis politiques au Québec - Aspects historiques (Montréal, Boréal Express, 1982): 141-154.

406. COULOMBE, Danielle. La femme des années trente: une image dans Châtelaine et les pages féminines du Country guide et de la Revue moderne, 1929-1939. Thèse de M.A., Université d'Ottawa, 1981.

407. DESLAURIERS, Nicole. Si mon père m'était conté. Montréal, Inédi, 1983. 346 p.

408. DESROSIERS, Denise, Joel W. GREGORY et Victor PICHÉ. La migration au Québec, syntèse et bilan bibliographique. Québec, Gouvernement du Québec, Ministère de l'immigration, 1981. $106 \mathrm{p}$.

409. DIONNE, René. «Guy Frégault écrivain à l'âge de l'interrogation», Pierre Savard, Guy Frégault (1918-1977) (Montréal, Bellarmin, 1981): 63-82.

410. DUCASSE, Russell. Le mode de scrutin au Québec: synthèse, chronologie, vocabulaire et bibliographie (1970-1982). Québec, Bibliothèque de l'Assemblée nationale, 1983. $85 \mathrm{p}$.

411. DUCROCQ-POIRIER, Madeleine. «Marie Le Franc sur les traces de Louis Hémon au Lac Saint-Jean», Saguenayensia, 25, 3 (juill.-sept. 1983): 73-76.

412. ELLENWOOD, Roy. «Morley Callaghan, Jacques Ferron, and the dialectic of gocd and evil», David Staines, The Callaghan symposium (Ottawa, University of Ottawa Press, 1981): 37-46.

413. ÉTHIER-BLAIS, Jean. «Frégault, biographe de Groulx», Pierre Savard, Guy Frégault (1918-1977) (Montréal, Bellarmin, 1981): 41-48.

414. FALARDEAU, Jean-Charles. «La correspondance Frégault-Groulx 1937-1965», Pierre Savard, Guy Frégault (1918-1977) (Montréal, Bellarmin, 1981): 49-62.

415. FAUCHER, Philippe et al. «L'aide financière directe au secteur manufacturier au Québec et en Ontario, 1960-1980», Journal of Canadian Studies / Revue d'études canadiennes, 18, 1 (print. 1983): 54-78.

416. FERLAND, Robert. Les commissions scolaires: onze années de statistiques sur les écoles et les clientèles, 1970-1971 à 1980-1981. [Québec], Gouvernement du Québec, Ministère de l'éducation, Direction des études économiques et démographiques, 1982. i, $594 \mathrm{p}$.

417. FINBOW, Robert. «The State Agenda in Quebec and Ontario, 1960-1980», Journal of Canadian Studies / Revue d'études canadiennes, 18, 1 (print. 1983): 117-135.

418. GAGNON, Claude-Marie. «L'influence d'un livre» - Histoire d'une âme de sainte Thérèse de l'Enfant Jésus», Benoit Lacroix et Jean Simard, Religion populaire - Religion de clercs? (Québec, Institut québécois de recherche sur la culture, 1984): 131-148.

419. GENEST, Jean. Joseph-Éna Girouard et son temps, 1855-1937. Drummondville (Québec), Société historique du centre du Québec, 1981. 48 p.

420. GODARD, Barbara. «Across frontiers: Callaghan in French», David Staines, The Callaghan symposium (Ottawa, University of Ottawa Press, 1981): 47-58.

421. GOLD, Gerald L. et Marc-Adélard TREMBLAY. «La formation de l'anthropologie du Québec 1960-1980», Marc-Adélard Tremblay, Conscience et enquête: l'ethnologie des réalités canadiennes (Ottawa, Musées nationaux du Canada, 1983): 52-94.

422. GOW, J. I. «Le syndicalisme des fonctionnaires du Québec, 1943-1964: l'histoire du Conseil général des employés de la Province de Québec», Revue canadienne de science politique / Canadian Journal of Political Science, 17, 1 (mars 1984): 145-156.

423. HAINAULT, Doris-Louise. «Problématique de la création chez Nelligan», Réjean Robidoux et Paul Wyzcynski, Crémazie et Nelligan (Montréal, Fides, 1981): 106-116. 
424. HAMEL, Thérèse. L'obligation scolaire au Québec: lieu et enjeu de la lutte des classes. Thèse de Ph.D., (sociologie-éducation), Université René Descartes, Paris V, Sorbonne, 1981. $448 \mathrm{p}$.

425. HAMELIN, Jean et Louise BEAUDOIN. «Les cabinets provinciaux 1867-1967», Vincent Lemieux, Personnel et partis politiques au Québec - Aspects historiques (Montréal, Boréal Express, 1982): 119-138.

426. HARVEY, Jean-Charles. Fear's folly (les demi-civilisés). Ottawa, Carleton University Press, $1982.178 \mathrm{p}$.

427. HÉMON, Louis. Maria Chapdelaine. Montréal, Boréal Express, 1983. xiii, 216 p.

428. HÉMON, Louis. Maria Chapdelaine. Montréal, La Presse, 1983. 158 p.

429. HÉMON, Louis. Maria Chapdelaine: récit du Canada français. Boucherville (Québec), Éditions de Mortagne, 1983. 222p.

430. HESBOIS, Laure. «Le signe poétique chez Émile Nelligan», Réjean Robidoux et Paul Wyczynski, Crémazie et Nelligan (Montréal, Fides, 1981): 95-105.

431. JEAN, Michèle. «Idola Saint-Jean, féministe (1880-1945)», Mon héroïne - Les lundis de l'histoire des femmes: an 1 (Montréal, Éditions du Remue-Ménage, 1981): 117-147.

432. JONES, Richard. Duplessis and the Union Nationale administration. Coll. «Historical booklet» no 35. Ottawa, Canadian Historical Association, 1983. 23 p.

433. LAFRANCE, Hélène. Yves Thériault ou la transgression des codes de l'institution littéraire québécoise. Thèse de M.A. (études française), Université de Sherbrooke, 1983. $220 \mathrm{p}$.

434. LAMY, Laurent. Architecture contemporaine au Québec, 1960-1970. Montréal, Éditions de l'Hexagone, 1983. $179 \mathrm{p}$.

435. LAPERRIÈRE, Guy. «Religion populaire, religion de clercs? - Du Québec à la France, 1972-1982», Benoit Lacroix et Jean Simard, Religion populaire - Religion de clercs? (Québec, Institut québécois de recherche sur la culture, 1984): 19-51.

436. LATREMOUILLE, Denise. «Dr. Joseph-Urgel Archambault, maire de Hull», Asticou. Revue d' histoire de l'Outaouais, 29 (déc. 1983): 3-9.

437. LEMELIN, André. Le déclin du port de Québec et la reconversion économique à la fin du $19^{e}$ siècle: une évaluation de la pertinence de l' hypothèse du «staple». Québec, Département d'économique, Faculté des sciences sociales, Université Laval, 1981. 45 p.

438. LEMIEUX, Vincent et François RENAUD. «Activités et stratégies des partis dans la région de Québec», Vincent Lemieux, Personnel et partis politiques au Québec - Aspects historiques (Montréal, Boréal Express, 1982): 175-204.

439. Les Rues de Cap-Rouge: historique de leurs noms. Cap-Rouge (Québec), Société historique du Cap-Rouge, 1981. [31] p.

440. LEVER, Denise. La tentation de la lumière chez Fernand Ouellette. Thèse de M.A., Université McGill, 1981.

441. LINTEAU, Augustine-M. Douce mémoire. [Charlesbourg], S.N., 1983. 139 p. (autobiographie).

442. McDOUGALL, Brian. Stanley Ryerson and the materialist conception of history: a study in the Stalinist distortion of Marxism. Thèse de M.A., Université de Carleton, 1982.

443. MEUNIER-TARDIF, Ghislaine. Vies de femmes. [Montréal], Libre expression, 1981. $199 \mathrm{p}$.

444. MONET-CHARTRAND, Simone. Ma vie comme rivière -2 vol. Montréal, Éditions du Remue-Ménage, 1981.

445. MORIN, André. K'émunération des enseignants: une comparaison Québec-Ontario, 19761977 à 1979-1980. [Québec], Gouvernement du Québec, Bureau de recherche sur la rémunération, $1982.87 \mathrm{p}$.

446. MORISSET, Michel. Agriculture familiale ou capitaliste au Québec au XXe siècle. Thèse de doctorat d'état, Université de Paris VIII, 1982. 593 p.

447. NORMANDIN, Marie-Josée. La démocratisation et le système de partis au Québec depuis 1960. Thèse de M.A., Université McGill, 1981.

448. PELLETIER, Charles, prés. «Charles Morency - Mémorable expédition», L'Écho des Basques, 4, 1 (déc. 1983): 16-19. (Expédition d'arpentage sur la pointe de Gaspé en 1927 pour départager des limites forestières). 
449. PETERSON, Olive MACKAY. The vanashing prospector. Ottawa, Borealis Press, 1981. 96 p. (autobiographie).

450. QUESNEL-OUELLET, Louise. «Les partis politiques locaux au Québec», Vincent Lemieux, Personnel et partis politiques au Québec - Aspects historiques (Montréal, Boréal Express, 1982): 277-306.

451. QUINN, Herbert F. «The formation and rise to power of the Union nationale», R. Douglas et Donald B. Smith, Readings in Canadian history - Post-confederation (Toronto, Holt, Rinehart and Winston, 1982): 433-446.

452. RIOU, Grégoire. «St-Fabien de Rimouski», L'Estuaire généalogique, 3, 9 (janv. 1984): 162-166. (Noms de personnes de Saint-Fabien qui se sont mariées ou qui sont décédées au Maine et à Fall River, Mass.)

453. RIOUX, Laurent. «Ouverture du deuxième rang ouest», L'Écho des Basques, 4, 1 (déc. 1983): 20-21. (de la paroisse de Trois-Pistoles).

454. RIOUX, Mozart, et al. «Ecole des Frères du Sacré-Coeur, 1928-1983», L'Écho des Basques, 4, 1 (déc. 1983): 22-31. (À Trois-Pistoles).

455. RIVARD, Gérard. L'institut coopératif Desjardins, 1963-1973. Trois-Rivières, Fédération des caisses populaires Desjardins du centre du Québec, [1981?]. 94 p.

456. ROME, David. Clouds in the thirties: on antisemitism in Canada, 1929-1939: a chapter on Canadian Jewish history. Montréal, [National Archives, Canadian Jewish Congress], 1977-1981. 13 vol.

457. Saint-Clément, 1881-1981. Saint-Clément (Québec), Le Comité du centenaire 1981. 319 p.

458. SIMARD, Luc. Estimation du revenu familial: Ville de Laval, région métropolitaine de Montréal, 1970-1980. Laval (Québec), Service des recherches et de la statistique. Ville de Laval, 1981. 22 p.

459. SIMARD, Sylvain. «Le «Journal du siège de Paris» face à l'histoire», Réjean Robidoux et Paul Wyczynski, Crémazie et Nelligan (Montréal, Fides, 1981): 49-64.

460. SPARKES, Wendell John. Arthur Tremblay's contribution to educational reform in Quebec: an analysis of annex 4. Thèse de M.A., Université McGill, 1981.

461. STIRLING, J. Craig. The St-Hilaire church interior decorations (1896-1900) of Ozias Leduc. Thèse de M.A., Université Concordia, 1982.

462. TISSOT, Georges. «Initiation et histoire - Le rite dans l'ordre de Jacques-Cartier», Benoit Lacroix et Jean Simard, Religion populaire - Religion de clercs? (Québec, Institut québécois de recherche sur la culture, 1984): 325-337.

463. TOURANGEAU, Rémi. Bibliographie du théâtre en Mauricie. Trois-Rivières, [Centre de documentation en lettres québécoises de l'Université du Québec à Trois-Rivières], $1981.2 \mathrm{vol}$.

464. VALLERAND, Noël. «Guy Frégault, haut fonctionnaire», Pierre Savard, Guy Frégault (1918-1977) (Montréal, Bellarmin, 1981): 83-91.

465. VANASSE, Diane. L'évolution de la population scolaire du Québec. Montréal, Institut de recherches politiques / Institute for the Research on Public Policy, 1981. xvii, 100 p.

466. WYCZYNSKI, Paul. « «Le vaisseau d'or» d'Émile Nelligan - Genèse, structure, signification», Réjean Robidoux et Paul Wyczynski, Crémazie et Nelligan (Montréal, Fides, 1981): 75-94.

467. WYDER, Patricia. The theatre arts programs at the Montreal anglophone CEGEP: a study of their history, philosophy and development from 1967-1980. Thèse de M.A., Université McGill, 1981.

VOIR AUSSI: $54 ; 55 ; 66 ; 67 ; 71 ; 75 ; 77 ; 83 ; 146 ; 148 ; 150 ; 151 ; 153 ; 154 ; 155 ; 157 ; 158$; $159 ; 161 ; 163 ; 164 ; 166 ; 169 ; 171 ; 172 ; 173 ; 174 ; 175 ; 176 ; 181 ; 182 ; 183 ; 184$; 186; 187; 189; 190; 192; 259; 276.

\section{4 - L'ONTARIO}

468. AARON, Daniel. «Morley Callaghan and the great depression», David Staines, The Callaghan symposium (Ottawa, University of Ottawa Press, 1981): 23-35.

469. ARKINSTALL, Margaret et Elizabeth PEARCE. Pioneer partners at St. Paul's, Hearst, Ontario. [Aylmer (Ont.)], 1983. 187 p. 
470. AYRE, David J. Universities and the Legislature: political aspects of the Ontario university question, 1868-1906. Thèse de Ph.D., Université de Toronto, 1981.

471. BARNES, Eleanor. Select committees of the Legislative Assembly of Ontario 1867-1978: a checklist of reports. Toronto, Legislative Library, Research and Information Services, 1983. x, $88 \mathrm{p}$.

472. BEATTIE, Mac. This Ottawa Valley of mine. Arnprior (Ont.), Beattie Music, [1983]. 1982. $264 \mathrm{p}$.

473. BUSH, Jack. Jack Bush: works on paper, 1958-1962: exhibition, March 18 to April 9, 1981. Toronto, Theo Waddington Galleries, [1981]. [12] p.

474. CAMERON, Barry. «Rhetorical tradition and the ambiguity of Callaghan's narrative rhetoric», David Staines, The Callaghan symposium (Ottawa, University of Ottawa Press, 1981): 67-76.

475. CARROLL, Sheldon S. «In memorian - J. Douglas Ferguson, F.R.N.S., F.C.N.R.S.», R. Paul Nadin-Davis et Frank Fesco, Numismatic Ottawa (Ottawa, City of Ottawa Coin Club, 1982): 3-6.

476. DAULT, Gary Michael. Barker Fairley portraits. Toronto, Methuen, 1981. xviii, 107 p.

477. DAVISON-WOOD, Karen. A Philistine culture?: literature, painting, and the newspapers in late Victorian Toronto. Thèse de Ph.D., Université Concordia, 1981.

478. DRUMMOND, Robert J. «Ontario Revenue Budgets 1960-1980», Canadian Journal of Canadian Studies / Revue d'études canadiennes, 18, 1 (print. 1983): 79-91.

479. EDEL, Léon. «Literature and journalism: the visible boundaries», David Staines, The Callaghan symposium (Ottawa, University of Ottawa Press, 1981): 7-22.

480. ESLER, J. Graham. «A pioneer Ottawa numismatist», R. Paul Nadin-Davis et Frank Fesco, Numismatic Ottawa (Ottawa, City of Ottawa Coin Club, 1982): 9-21. (F.-X. Paquet).

481. GREENWOOD, John Orville. Namesakes, 1956-1980. Cleveland, Freshwater Press, 1981. $\mathrm{xi}, 627$ p. (Navigation sur les Grands lacs).

482. HEIDORN, K. C. Air quality trends in Ontario, 1971-1979. Toronto, Ontario Ministry of the Environment, Air Quality and Meteorology Section, 1981. $53 \mathrm{p}$.

483. HOTSON, Fred W. The de Havilland Canada story. Toronto, Canay Books, 1983. 244 p.

484. JOHNSTON, Grace. Memories of the lockstations at Long Island, Black Rapids, Hog's Back and Hartwell's Hartwell's down to the Ottawa basin. Gloucester (Ont.), Gloucester Historical Society, 1982. 18 p.

485. KEALEY, Gregory S. «Hogtown: Working class Toronto at the turn of the century», R. Douglas et Donald B. Smith. Readings in Canadian history - Post-confederation (Toronto, Holt, Rinehart and Winston, 1982): 175-195.

486. KHONDAKAR, Niazamuddin. Some changes in socioeconomic and spatial characteristics of ethnic groups in London, Ontario, 1961-1971. Thèse de Ph.D. University of Western Ontario, 1981.

487. KILLAN, Gerald. David Boyle: from artisan to archaelogist. Toronto, University of Toronto Press, 1983. x.vii, $276 \mathrm{p}$.

488. KOOP, Alvin et Sheila McMURRICH-KOOP. Older voices among us. Erin (Ont.), Boston Mills Press, $1981.96 \mathrm{p}$.

489. LEGENDRE, Anne Carmelle. The Baptist contribution to nineteenth century education for women: an examination of Moulton College and McMaster University. Thèse de M.A., Université McMaster, 1981.

490. McDONALD, Larry. «The civilized ego and its discontents: a new approach to Callaghan», David Staines, The Callaghan symposium (Ottawa, University of Ottawa Press, 1981): 77-94.

491. McKAY, Paul. Electric empire: the inside story of Ontario Hydro. Toronto, Between the Lines, 1983. $298 \mathrm{p}$.

492. MARIN, Clive. Stormont, Dundas and Glengarry, 1945-1978. Belleville (Ont.), Mika, 1982. $644 \mathrm{p}$

493. MORLEY, Patricia. «Morley Callaghan: magician and illusionist», David Staines, The Callaghan symposium (Ottawa, University of Ottawa Press, 1981): 59-65.

494. PAPP-ZUBRITS, Susan M. «Oral history: reflections of the members of three waves of hungarian imrnigrants in Ontario», Martin L. Kovacs, Roots and realities among east- 
ern and central europeans (Edmonton, Central and East European Studies Association of Canada, 1983): 155-164.

495. REID, Babe et Roberta FITZGERALD. Malachi. [Malachi? (Ont.), s.n.], 1981. 240 p.

496. SANDERS, Mary. St. Thomas is proud of: centennial biographical sketches. St Thomas (Ont.), M. Sanders, 1981. 113 p.

497. SIMON, Victor. Le règlement XVII: sa mise en vigueur à travers l'Ontario, 1912-1927. Coll. «Documents historiques» no 78. Sudbury, Société historique du Nouvel Ontario. 1983. $58 \mathrm{p}$.

498. STAINES, David. «Morley Callaghan: the writer and his writings», David Staines, The Gallaghan symposium (Ottawa, University of Ottawa Press, 1981): 111-121.

499. SUFRIN, Eileen. The Eaton drive: the campaign to organize Canada's largest department store, 1948 to 1952 . Toronto, Fitzhenry and Whiteside, 1983. $240 \mathrm{p}$.

500. VALLIÈRES, Gaétan. «The Franco-ontarian experience», Raymond Breton et Pierre Savard, The Quebec and Acadian diaspora in North America (Toronto, The multicultural history society of Ontario, 1982): 183-196.

501. WINZER, Margret. An examination of some selected factors that affected the education and socialization of the deaf of Ontario, 1870-1900. Thèse de Ph.D., Université de Toronto, 1981.

502. WINSTOW, David. Tom Thomson and the Group of Seven: selected works from the collection of the Art Gallery of Ontario. Toronto, The art Gallery of Ontario, 1982. 20 p.

503. ZEMAN, John Paul. A search for succesful governmental structure: urban political reform in Guelph, 1900-1925. Thèse de M.A., Université de Guelph, 1982.

VOIR AUSSI: 96; 193; 194; 196; 198; 199; 202; 205; 206; 208; 210; 213; 215; 221; 222; 224; $225 ; 332 ; 389 ; 394 ; 412 ; 415 ; 417 ; 420 ; 462$.

\section{5-L'OUEST}

504. A Brief history of Beacon Hill Park. Victoria (C.-B.), s.n., 1982. 30 p.

505. ANDERSON, Alan B. «German settlements in Saskatchewan», Martin L. Kovacs, Roots and realities among eastern and central Europeans (Edmonton, Central and East European Studies Association of Canada, 1983): 175-221.

506. ARTIBISE, Alan F.J. «Boosterism and the development of prairies cities, 1871-1913», Alan F.J. Artibise, Town and city - Aspects of Western canadian urban development (Edmonton, University of Regina, 1981): 209-235.

507. ARTIBISE, Alan F.J. «The urban west; the evolution of prairie towns and cities to 1930», R. Douglas et Donald B. Smith, Readings in Canadian history - Post-confederation (Toronto, Holt, Rinehart and Winston, 1982): 247-269.

508. BARMAN, Jean. "The world that British settlers made: class, ethnicity and private education in the Okanagan valley», W. Peter Ward et Robert A.J. McDonald, British Columbia: Historical readings (Vancouver, Douglas \& McIntyre, 1981): 600-626.

509. BASKERVILLE, Peter A. et Chad M. GAFFIELD. «The Vancouver Island Project: Historical Research and Archival Practice», Archivaria, 17 (hiv. 1983-1984): 173-187.

510. BATCHELOR, Bruce E. «Economy and society in Central Alberta on the eve of autonomy: the case of the SLHC», Donald H. Akenson, Canadian papers in rural history Volume III (Gananoque, Langdale Press, 1982): 148-155.

511. BERCUSON, David Jay. «Labour radicalism and the western Industrial Frontier: 18971919», W. Peter Ward et Robert A.J. McDonald, British Columbia: Historical readings (Vancouver, Douglas \& McIntyre, 1981): 451-473.

512. BERCUSON, David Jay. «Labour radicalism and the western industrial frontier: 1887 1919», R. Douglas et Donald B. Smith, Readings in Canadian history - Post-confederation (Toronto, Holt, Rinehart and Winston, 1982): 156-175.

513. BETKE, Carl. The development of urban community in prairie Canada: Edmonton, 1892 1921. Thèse de Ph.D., Université d'Alberta, 1981. 
514. BETKE, Carl. «The original city of Edmonton: a derivative prairie urban community», Alan F.J. Artibise, Town and city - Aspects of Western canadian urban development (Edmonton, University of Regina, 1981): 309-345.

515. BOLTON, Ken et al. The Albertans. Edmonton, Lone Pine Media Productions, 1981. $176 \mathrm{p}$.

516. BOWMAN, Phyllis. The city of rainbows! Prince Rupert (C.-B.), P. Bowman, 1982. 280 p. (Prince Rupert).

517. BRENNAN, J. William. "Business-government co-operation in townsite promotion in Regina and Moose Jaw, 1882-1903», Alan F.J. Artibise, Town and city - Aspects of Western canadian urban development (Edmonton, University of Regina, 1981): 95120.

518. BROWN, Rosemary Alice. Katharine Emma Maltwood, artist, 1878-1961. Victoria (C.B.), Sono Nis Press, 1981. 64 p.

519. BROWN, Roy. The Brandon Hill connection: a souvenir for Brandon, Manitoba's centenary. Brandon (Man.), Tourism unlimited, 1982. 116 p. (Brandon, Man.).

520. BUYNIAK, Victor O. «Doukhobors, molokans and spkvoroda's teachings», Martin L. Kovacs, Roots and realities among eastern and central Europeans (Edmonton, Central and East European Studies Association of Canada, 1983): 13-23.

521. CARELESS, J.M.S. «The myth of the downtrodden west», R. Douglas Francis et Donald B. Smith, Readings in Canadian history - Post-confederation (Toronto, Holt, Rinehart and Winston, 1982): 63-71.

522. CAVELL, Edward. A delicate wilderness: the photography of Elliott Barnes, 1905-1914. Banff (Alberta), Altitude Pub. \& The Whyte Foundation, 1983. 47 p.

523. CLARK, Malcolm John Roy. A statistical overview of water quality analyses for British Columbia 1965-1976. Victoria, Environmental Protection, 1978. i. 47 p.

524. CLARK, Samuel D. «Mining society in British Columbia and the Yukon», W. Peter Ward et Robert A.J. McDonald, British Columbia: Historical readings (Vancouver, Douglas \& McIntyre, 1981): 215-231.

525. COULTER, Rebecca. «Not to punish but to reform»: Juvenile delinquency and children's protection act in Alberta, 1909-1929», Patricia T. Rooke et R.L. Schnell, Studies in childhood history - A canadian perspective (Calgary, Detselig, 1982): 167-184.

526. CULLEN, Mark Dowdell. The evolution of petroleum concessions in Iran and Alberta. Thèse de L.L.M., Université d'Alberta, 1981.

527. DAHLIE, Jorgen. «Learning on the frontier: scandinavian immigrants and education in Western Canada», W. Peter Ward et Robert A.J. McDonald, British Columbia: Historical readings (Vancouver, Douglas \& McIntyre, 1981): 627-638.

528. DEN OTTER, Andy A. «Lethbridge: outpost of a commercial empire, 1885-1906», Alan F.J. Artibise, Town and city - Aspects of Western canadian urban development (Edmonton, University of Regina, 1981): 177-202.

529. DEROSBY-ROUSSY, Marie-Ange. Magpie, petit coin ignoré de la Côte Nord. Sept-Îles (Québec), M.-A. Dérosby-Roussy, 1983. 151 p.

530. DUFFY, Dennis. Imagine please: early radio broadcasting in British Columbia. Victoria, Sound and Moving Image Division, Provincial Archives of British Columbia, 1983. iv, $92 \mathrm{p}$.

531. DYCK, Henry. Jacob John Siemens and the co-operative movement in Southern Manitoba 1929-1955. Thèse de M.A., Université du Manitoba, 1982.

532. Early days to modern ways: history of Liberty and district. Liberty (Sask.), Liberty Optimist Club. 1982. x, $447 \mathrm{p}$.

533. FORAN, Max. The civic corporation and urban growth: Calgary, 1884-1930. Thèse de Ph.D., Université de Calgary, 1981.

534. FORAN, Max. L. «The making of a booster: Wesley Fletcher Orr and nineteenth century Calgary», Alan F.J. Artibise, Town and city - Aspects of Western canadian urban development (Edmonton, University of Regina, 1981): 289-307.

535. FORWARD, Charles N. «The Evolution of Victoria's functional character», Alan F.J. Artibise, Town and city - Aspects of Western canadian urban development (Edmonton, University of Regina, 1981): 347-370. 
536. GIBBARD, John E. «Agricultural settlement of the Fraser Valley», The Fraser's history from glaciers to early settlements (Burnaby (C.-B.), Burnaby historical society, [1981?]): 39-50.

537. GILPIN, John. «Failed metropolis: the city of Stratchcona, 1891-1912», Alan F.J. Artibise, Town and city - Aspects of Western canadian urban development (Edmonton, University of Regina, 1981): 259-288.

538. GOUGH, Barry $M$. «The royal navy's legacy to the royal canadian navy in the Pacific 1880-1914», James A. Boutilier, The RCN in retrospect 1910-1968 (Vancouver, University of British Columbia Press, 1982): 1-12.

539. HATCHER, Colin K. Edmonton's electric transit: the story of Edmonton's streetcars and trolley buses. Toronto, Railfare Enterprises, 1983. 209 p.

540. HOLMES, Peggy. It could have been worse. Toronto, Totem Books, 1983. 109 p. (autobiographie).

541. HUME, David. «Life's Embarrassing Moments - Right Treaty, Wrong Adhesion: John Semmens and the Split Lake Indians», Archivaria, 17 (hiv. 1983-1984): 261-265.

542. JAMIESON, Stuart. «Regional factors in industrial conflict: the case of British Columbia», W. Peter Ward et Robert A.J. McDonald, British Columbia: Historical readings (Vancouver, Douglas \& McIntyre, 1981): 500-514.

543. JONES, David C. « «We can't live on air all the time»: Country life and the prairie child», Patricia T. Rooke et R.L. Schnell, Studies in childhood history - A canadian perspective (Calgary, Detselig, 1982): 185-202.

544. KING, Stirling. Changing challenge: the 75-year story of Sterling Distributors Limited. Saskatoon, J.S. Laxdal and Associates, 1982. x, 128 p.

545. KLASSEN, Henry C. "In search of neglected and delinquant children: the Calgary children's aid society, 1909-1920», Alan F.J. Artibise, Town and city-Aspects of Western canadian urban development (Edmonton, University of Regina, 1981): 375-391.

546. KURELEK, William et Joan MURRAY. Kurelek's vision of Canada. Edmonton, Hurtig, 1983. $80 \mathrm{p}$.

547. LALONDE, André-N. «Le «Patriote de l'ouest» and French settlement on the prairies, 1910-1930», Raymond Breton et Pierre Savard, The Quebec and Acadian diaspora in North America (Toronto, The multicultural history society of Ontario, 1982): 123-134.

548. LAWSON, John Howard. Central place change in Southern Alberta, 1951-1978. Thèse de M.A., Université de Calgary, 1981.

549. LEAH, Vince. Alarm of fire: 100 years of firefighting in Winnipeg, 1882-1982. Winnipeg, Firefighters Burn Fund, 1982. 144 p.

550. LEE, Ellen. Fouilles archéologiques au lieu historique national de Batoche, 1982. Coll. «Bulletin de recherches» no 191. Ottawa, Parcs Canada, 1983. 9 p.

551. LEWIS, Norah. «Physical perfection for spiritual welfare: health care for the urban child, 1900-1939», Patricia T. Rooke et R.L. Schnell, Studies in childhood history - A canadian perspective (Calgary, Detselig, 1982): 135-166.

552. Lines of the past. Preeceville (Sask.), Preeceville Historical Society, 1982. vi, 777 p.

553. LYMAN, Standford M. «Contrasts in community organization of Chinese and Japanese in North America», W. Peter Ward et Robert A.J. McDonald, British Columbia: Historical readings (Vancouver, Douglas \& McIntyre, 1981): 639-656.

554. Manitoba's research on aging: an annotated bibliography, 1950-1982. [Winnipeg], Manitoba Association on Gerontology, [1982]. v, 269 p.

555. MARDIROS, Tony. «William Irvine and the Farmer Labour movement in Alberta», Donald C. Kerr, Western Canadian politics: The radical tradition (Edmonton, Newest Institute for western Canadian studies, 1981): 17-24.

556. Minto memoirs: history of Minto and district. Winnipeg, Inter-Collegiate Press, 1979. $320 \mathrm{p}$.

557. MORTON, William Lewis. «The Western Progressive movement, 1919-1921», R. Douglas et Donald B. Smith, Readings in Canadian history - Post-Confederation (Toronto, Holt, Rinehart and Winston, 1982): 362-376.

558. MURDOCK, Gladys. Towering timbers and me. Hantsport (N.-É.), Lancelot Press. 1982. 104 p. (Autobiographie). 
559. MURRAY, Joan. Kurelek's vision of Canada. Oshawa (Ont.), Robert McLaughlin Gallery, $1982.80 \mathrm{p}$.

560. McCORMACK, A. Ross. «The industrial workers of the world in western Canada: 19051914», W. Peter Ward et Robert A.J. McDonald, British Columbia: Historical readings (Vancouver, Douglas \& McIntyre, 1981): 474-499.

561. McCRORIE, James. «The CCF and the tradition of agrarian radicalism», Donald C. Kerr, Western Canadian politics: The radical tradition (Edmonton, Newest Institute for western canadian studies, 1981): 25-30.

562. MACDONALD, Norbert. «The Canadian Pacific Railway and Vancouver's development to 1900», W. Peter Ward et Robert A.J. McDonald, British Columbia: Historical readings (Vancouver, Douglas \& McIntyre, 1981): 396-425.

563. McDONALD, Robert A.J. «Victoria, Vancouver, and the economic development of British Columbia, 1886-1914», Alan F.J. Artibise, Town and city - Aspects of Western canadian urban development (Edmonton, University of Regina, 1981): 31-55.

564. McDONALD, Robert A.J. «Victoria, Vancouver, and the economic development of British Columbia, 1886-1914», W. Peter Ward et Robert A.J. McDonald, British Columbia: Historical readings (Vancouver, Douglas \& McIntyre, 1981): 369-395.

565. McDOUGALL, John. In the days of the Red River Rebellion. Edmonton, University of Alberta Press, 1983. xxxviii, 303 p.

566. McKAGUE, Ormond Knight. Socialist education in Saskatchewan, 1942-1948: a study in ideology and bureaucracy. Thèse de Ph.D., Université de l'Orégon, 1981.

567. ORMSBY, Margaret A. «T. Dufferin Pattullo and the little New Deal», W. Peter Ward et Robert A.J. McDonald, British Columbia: Historical readings (Vancouver, Douglas \& McIntyre, 1981): 533-554.

568. OWRAM, Doug. «Reluctant hinterland», Larry Pratt et Garth Stevenson, Western separatism - the myths, realities and dangers (Edmonton, Hurtig, 1981): 45-64.

569. PALMER, Howard. «Reluctant hosts: Anglo-Canadian views of multiculturalism in the twentieth century», R. Douglas et Donald B. Smith, Readings in Canadian history Post-confederation (Toronto, Holt, Rinehart and Winston, 1982): 123-139.

570. PARKER, Ian D. «Simon Fraser Tolmie: The last conservative premier of British Columbia», W. Peter Ward et Robert A.J. McDonald, British Columbia: Historical readings (Vancouver, Douglas \& McIntyre, 1981): 517-532.

571. PATERSON, D.G. «Eurepean financial capital and British Columbia: an essay on the role of the regional entrepreneur», W. Peter Ward et Robert A.J. McDonald, British Columbia: Historical readings (Vancouver, Douglas \& McIntyre, 1981): 328-342.

572. PATERSON, D.G. «The north pacific seal hunt, 1886-1910: Rights and regulations», W. Peter Ward et Robert A.J. McDonald, British Columbia: Historical readings (Vancouver, Douglas \& McIntyre, 1981): 343-366.

573. PENNER, Norman. «The Western canadian left - in retrospect», Donald C. Kerr, Western Canadian politics: the radical tradition (Edmonton, Newest Institute for western canadian studies, 1981): 3-16.

574. PHILLIPS, Paul. «The prairie urban system, 1911-1961: specialization and change», Alan F.J. Artibise, Town and city - Aspects of Western canadian urban development (Edmonton, University of Regina, 1981): 7-30.

575. POTYONDI, Barry. «In quest of limited urban status: the town-building process in Mennedosa, 1879-1906», Alan F.J. Artibise, Town and city - Aspects of Western canadian urban development (Edmonton, University of Regina, 1981): 121-146.

576. POWELL, Karen L. Reference guide to Alberta government committees, 1905-1980. Edmonton, Alberta Legislative Library, Cooperative Government Library Services, 1982. $150 \mathrm{p}$.

577. RALSTON, Keith. «Patterns of trade and investment on the Pacific coast, 1867-1892: The case of the British Columbia salmon canning industry», W. Peter Ward et Robert A.J. McDonald, British Columbia: Historical readings (Vancouver, Douglas \& McIntyre, 1981): 296-305.

578. Reflections of Radisson: 1902-1982. Radisson (Sask.), Radisson and District Historical Society, 1982. x, $691 \mathrm{p}$. 
579. Regard sur Maillardville: avec la liste de mariages célébrés de 1911 à 1950. Vancouver, Société historique franco-colombienne, 1980. 32 p.

580. REID, David J. «Company mergers in the Fraser River Salmon canning industry, 18851902», W. Peter Ward et Robert A.J. McDonald, British Columbia: Historical readings (Vancouver, Douglas \& McIntyre, 1981): 306-327.

581. RICHARDS, John. «Populism and the West», Larry Pratt et Garth Stevenson, Western separatism - The myths, realities and dangers (Edmonton, Hurtig, 1981): 65-84.

582. ROY, Patricia E. «British Columbia's fear of Asians, 1900-1950», W. Peter Ward et Robert A.J. McDonald, British Columbia: Historical readings (Vancouver, Douglas \& McIntyre, 1981): 657-670.

583. ROY, Patricia E. «Citizens without votes: East Asians in British Columbia, 1872-1947», Jorgen Dahlie et Tissa Fernando, Ethnicity, Power and politics in Canada (Toronto, Methuen, 1981): 151-171.

584. ROY, Patricia E. «Vancouver: «The Mecca of The unemployed», 1907-1929», Alan F.J. Artibise, Town and city - Aspects of Western canadian urban development (Edmonton, University of Regina, 1981): 393-413.

585. SAGE, Walter N. «British Columbia becomes Canadian (1871-1901)», R. Douglas Francis et Donald B. Smith, Readings in Canadian history - Post-confederation (Toronto, Holt, Rinehart and Winston, 1982): 10-20.

586. SAVAGE, Leslie. «Perspectives on illegitimacy: the changing role of the sisters of Misericordia in Edmonton, 1900-1906», Patricia T. Rooke et R.L. Schnell, Studies in childhood history - A Canadian perspective (Calgary, Detselig, 1982): 105-133.

587. SELWOOD, H. John et Evelyn BARIL. «The Hudson's bay company and prairie town development, 1870-1888», Alan F.J. Artibise, Town and city - Aspects of Western canadian urban development (Edmonton, University of Regina, 1981): 61-94.

588. SMITH, Allan. «The writing of British Columbia history», W. Peter Ward et Robert A.J. McDonald, British Columbia: Historical readings (Vancouver, Douglas \& McIntyre, 1981): 5-34.

589. SMITH, Andrea Barbara. The origins of the NPA: a study in Vancouver politics 19301940. Thèse de M.A., Université de Colombie-Britanique, 1983.

590. STANLEY, George F.G. «Louis Riel: Patriot or rebel?», R. Douglas Francis et Donald B. Smith, Readings in Canadian history - Post-confederation (Toronto, Holt, Rinehart and Winston, 1982): 71-92.

591. STOBBE, Abe John. South Abbotsford Mennonite Brethren Church: a history from 19321982. Abbotsford (C.-B.), The Church, 1982. 112 p.

592. SWAINSON, Donald. «Canada annexes the west: Colonial status confirmed», R. Douglas Francis et Donald B. Smith, Readings in Canadian history - Post-confederation (Toronto, Holt, Rinehart and Winston, 1982): 45-63.

593. The Bend: a history of West Lethbridge. Lethbridge (Alberta), West Lethbridge History Book Society, 1982. vi, 261 p.

594. The Best of Humboldt. Humboldt (Sask.), Humboldt Journal, 1982. viii, 648 p.

595. «The CCF in Saskatchewan», Donald C. Kerr, Western Canadian politics: The Radical tradition (Edmonton, Newest Institute for western canadian studies, 1981): 31-64.

596. THOMAS, Lewis H. «Saskatoon, 1883-1920: the formative years», Alan F.J. Artibise, Town and city - Aspects of Western canadian urban development (Edmonton, University of Regina, 1981): 237-258.

597. THOMPSON, John H. «The beginning of our regeneration: the great war and western canadian reform», R. Douglas et Donald B. Smith, Readings in Canadian history Post-confederation (Toronto, Holt, Rinehart and Winston, 1982): 287-303.

598. THORNER, T. et N. WATSON. «Patterns of prairie crime: Calgary, 1875-1939», Louis A. Knafla, Crime and Criminal justice in Europe and Canada (Waterloo, Wilfrid Laurier University Press, 1981): 219-255.

599. 21 ans de théâtre en français à Vancouver, C.C. 1946-1967: Histoire de la Troupe Molière. Vancouver, Société historique franco-colombienne, 1982. $118 \mathrm{p}$. 
600. VOISEY, Paul. «Boosting the small prairie town, 1904-1931: an example for southern Alberta», Alan F.J. Artibise, Town and city - Aspects of Western canadian urban development (Edmonton, University of Regina, 1981): 147-176.

601. WARD, W. Peter. «Class and race in the social structure of British Columbia, 1870-1939», W. Peter Ward et Robert A.J. McDonald, British Columbia: Historical readings (Vancouver, Douglas \& McIntyre, 1981): 581-599.

602. Watercolour painting in Saskatchewan, 1905-1980: Mendel Art Gallery, Saskatoon, December 4, 1980 January 4, 1981. Saskatoon, the Gallery, 1981. $43 \mathrm{p}$.

603. WEAVER, John $C$. «The property industry and land use controls: the Vancouver experience, 1910-1945», W. Peter Ward et Robert A.J. McDonald, British Columbia: Historical readings (Vancouver, Douglas \& McIntyre, 1981): 426-448.

604. YEDLIN, Tova. «Germans from Russia in Alberta: an introduction», Martin L. Kovacs, Roots and realities among eastern and central Europeans (Edmonton, Central and East European Studies Association of Canada, 1983): 223-232.

605. YOUNG, Walter D. «Ideology, personality and the origin of the CCF in British Columbia», W. Peter Ward et Robert A.J. McDonald, British Columbia: Historical readings (Vancouver, Douglas \& McIntyre, 1981): 555-577.

VOIR AUSSI: 8 ; 11; 12; 32; 39; 230; 231; 233; 238; 303; 350; 358 .

\section{6- LE NORD}

606. BERTON, Pierre. The Klondike quest: a photographic essay, 1897-1899. Toronto, McClelland and Stewart, 1983. 239 p.

607. CHRISTIE, R.L. et J. Wm. KERV. "Geological exploration of the Canadian arctic islands», Morris Zaslow, Un siècle des îles arctiques du Canada / 1880-1980 / A century of Canada's arctic islands (S.L., La société royale du Canada, 1981): 187-202.

608. COOKE, Alan. "A gift outright: the exploration of the Canadian arctic islands after 1880", Morris Zaslow, Un siècle des îles arctiques du Canada / 1880-1980 / A century of Canada's arctic islands (S.L., La société royale du Canada, 1981): 51-60.

609. CSEREPY, F.A.E. «New styles in administration since 1945», Morris Zaslow, Un siècle des îles arctiques du Canada / 1880-1980 / A century of Canada's arctic islands (S.L., La société royale du Canada, 1981): 275-290.

610. CUMMING, Gerald G. «Archival Detective Work: The Case of the Yukon Field Force Diary», Archivaria, 17 (hiv. 1983-1984): 248-260.

611. DEBICKI, R.L. Industrie minière du Yukon, 1941 à 1959. Ottawa, Affaires indiennes et du Nord Canada, 1983. viii, 138 p.

612. DIUBALDO, Richard J. «The role of the arctic islands in defence», Morris Zaslow, Un siècle des îles arctiques du Canada / 1880-1980 / A century of Canada's arctic islands (S.L., La société royale du Canada, 1981): 93-110.

613. DUNBAR, M.J. «The history of oceanographic research in the Waters of the Canadian arctic islands», Morris Zaslow, Un siècle des îles arctiques du Canada / 1880-1980 / A century of Canada's arctic islands (S.L., La société royale du Canada, 1981): 141152.

614. GREENAWAY, K.R. "Aviation in the arctic islands», Morris Zaslow, Un siècle des îles arctiques du Canada / 1880-1980 / A century of Canada's arctic islands (S.L., La société royale du Canada, 1981): 79-92.

615. JONES, Gordon H. «Economic development - oil and gas», Morris Zaslow, Un siècle des îles arctiques du Canada / 1880-1980 / A century of Canada's arctic islands (S.L., La société royale du Canada, 1981): 221-230.

616. LEEMING, J.M. «HMCS Labrador and the Canadian arctic», James A. Boutilier, The $R C N$ in retrospect 1910-1968 (Vancouver, University of British Columbia Press, 1982): 286-307.

617. LLOYD, Trevor. «Canada and the circumpolar world-comparisons and challenges», Morris Zaslow, Un siècle des îles arctiques du Canada / 1880-1980 / A century of Canada's arctic islands (S.L., La société royale du Canada, 1981): 309-318. 
618. MACDONALD, S.D. «Scientific progress: terrestrial biology, an overview», Morris Zaslow, Un siècle des îles arctiques du Canada / 1880-1980 / A century of Canada's arctic islands (S.L., La société royale du Canada, 1981): 171-186.

619. ORVING, Svenn. "A century of arctic meteorology: from discovery to science», Morris Zaslow, Un siècle des îles arctiques du Canada / 1880-1980 / A century of Canada's arctic islands (S.L., La société royale du Canada, 1981): 131-140.

620. PHARAND, Donat. «Canada's jurisdiction in the arctic», Morris Zaslow, Un siècle des îles arctiques du Canada / 1880-1980 / A century of Canada's arctic islands (S.L., La société royale du Canada, 1981): 111-130.

621. POUNDER, E.R. «Ice, snow and permafrost research», Morris Zaslow, Un siècle des îles arctiques du Canada / 1880-1980 / A century of Canada's arctic islands (S.L., La société royale du Canada, 1981): 163-170.

622. PULLEN, T.C. "The development of arctic ships», Morris Zaslow, Un siècle des îles arctiques du Canada / 1880-1980 / A century of Canada's arctic islands (S.L., La société ròyale du Canada, 1981): 153-162.

623. ZASLOW, Morris. "Administrating the arctic islands 1880-1940: policemen, missionaries, fur traders», Morris Zaslow, Un siècle des îles arctiques du Canada / 1880-1980 / A century of Canada's arctic islands (S.L., La société royale du Canada, 1981): 6178 .

VOIR AUSSI: 15; 29; 40; 232; 239; 242; 256; 378; 524.

\section{V - HISTOIRE GÉNÉRALE}

624. COLLINS, Paul et Norman SHAFFE. Rencontre Canada. Toronto, Oxford University Press, 1981. 319 p.

625. METCALFE, William. Understanding Canada. A multidisciplinary introduction to Canadian studies. New York, New York University Press, 1982. xii, 621 p.

626. MOIR, Michael B. «Scottish Manuscripts in Canadian Repositories», Archivaria, 17 (hiv. 1983-1984): 145-161.

\section{VI - INSTRUMENTS DE TRAVAIL}

627. CHARBONNEAU, Bernard, resp. «Index de 1959 à 1982», Saguenayensia, 25, 4 (sept.déc. 1983): 85-162.

628. DODDS, Gordon. «Canadian Archival Literature: A Bird's-Eye View», Archivaria, 17 (hiv. 1983-1984): 18-40.

629. INGLES, Ernest B. «For History's Sake: The Work of the Canadian Institute for Historical Microreproductions», Archivaria, 17 (hiv. 1983-1984): 233-247.

630. LAROSE, André. «Bibliographie courante sur l'histoire de la population canadienne et la démographie historique au Canada, 1981», Histoire sociale / Social history, 15, 30 (nov. 1982): 489-494.

631. LAROSE, André. «Bibliographie courante sur l'histoire de la population canadienne et la démographie historique au Canada, 1982», Histoire sociale / Social history, 16, 32 (nov. 1983): 443-449.

632. ROBERGE, Michel, «SAPHIR: la mémoire des Québécois», Archivaria, 17 (hiv. 19831984): 188-200.

VOIR AUSSI: 43; 46; 56; 57; 58; 59; 83; 113; 169; 221; 243; 255; 273; 281; 375; 380; 384; $408 ; 410 ; 416 ; 463 ; 471 ; 498 ; 554 ; 576 ; 606$.

\section{VII - GÉNÉALOGIE}

633. BACON, P. René. «Louis-Denis Bacon et sa descendance chez les Montagnais», Saguenayensia, 25, 3 (juill.-sept. 1983): 78-81

634. BEARS, Austin. Bears genealogy. Clyde River (I.-P.-É.), A. Bears, 1982. xiii, 268 p. 
635. BÉRUBÉ, Laurent. «L'ancêtre Damien Bérubé», L'Écho des Basques, 4, 1 (déc. 1983): 53-56.

636. CARON, Marie-Ange. «Ross: une autre famille souche», L'Estuaire généalogique, 3, 9 (janv. 1984): 174.

637. CARROLL, Donald Livingston. Robert's bairns. Iona Station (Ont.), D.L. Carroll. 1983. $459 \mathrm{p}$.

638. CLAVEAU, Robert et Louiselle B.-CLAVEAU. «Inventaire des contrats de mariage déposés à Rimouski (7⿳े̀me partie)», L'Estuaire généalogique, 3, 9 (janv. 1984): 169-172.

639. COUTU, Hector. Lagimodiere and their descendants, 1635-1885. Edmonton, Co-op Press, $1980.97 \mathrm{p}$.

640. HILL, Isabel Louise. The old burying ground, Fredericton N.B. Fredericton (N.-B.), Fredericton Heritage Trust, 1981. 2 vol.

641. JOWSEY, Joan. Thomas Jowsey, his descendants and other pioneer families of Eardley Township, Quebec. [Aylmer (Québec), J. Jowsey], 1981. vi, 141 p.

642. Library list, Kingston Branch, Ontario Genealogical Society. [Kingston], The Branch, 1982, iv, [16] p.

643. Ontario cemetery recordings: list no 1. Toronto, Ontario genealogical Society, [1982]. $20 \mathrm{p}$.

644. PROVOST, Roland. «Sainte-Anne-des-Monts, Activités généalogiques à la Société d'histoire et d'archéologie des Monts», L'Estuaire généalogique, 3, 9 (janv. 1984): 159161 .

645. SISSON, Leatha BOUDREAU. An index of family tree climbers, New Brunswick, Nova Scotia and Maine, Upper Kent (N.-B.), Sisson Genealogical Publications [1981?]. $38 \mathrm{p}$.

646. WALKER, Harriet. Issac Gilbert, United Empire Loyalist pioneer of Woodhouse Township, Norfolk County, Canada, 1742-1822: his descendants. Simcoe (Ont.), H. Walker, 1981. 583, 2 p.

647. WRIGHT, Esther CLARK. Planters and pioneers. [Wolfville (N.-É.), E.C. Wright], 1982. $334 \mathrm{p}$.

\section{VIII - HISTORIOGRAPHIE}

VOIR: 41; 45; 77; 87; 99; 133; 177; 209; 240; 276; 289; 401; 442. 